\title{
Durability evaluation of self-compacting concrete with recycled aggregates from the precast industry
}

\section{Sara Almeida Santos}

Instituto Superior Técnico, Universidade de Lisboa, Lisbon, Portugal

Pedro Raposeiro da Silva

CERIS-ICIST, Instituto Superior de Engenharia de Lisboa,

Instituto Politécnico de Lisboa, Lisbon, Portugal

\author{
Jorge de Brito \\ CERIS-ICIST, Instituto Superior Técnico, Universidade de Lisboa, Lisbon, \\ Portugal (corresponding author: jb@civil.ist.utl.pt)
}

This paper describes an experimental campaign developed with the aim of evaluating the influence of the incorporation of fine and coarse recycled aggregates (FRA and CRA, respectively) on the durability properties of selfcompacting concrete (SCC). The main objective is to provide the precast industry with an alternative way of disposal and recovery of self-generated waste, minimising the consumption of natural resources and, consequently, significantly reducing the environmental impact associated with the manufacture of concrete. For this purpose, two families of concrete were produced, distinct in terms of the compressive strength of the source concrete of the recycled aggregates (45 $\mathrm{MPa}$ and $65 \mathrm{MPa}$ ), with FRA/CRA incorporation ratios of 0/0\%, 25/25\%, 50/50\%, 0/100\% and $100 / 0 \%$. To evaluate the durability of the concretes, tests for water absorption, capillary absorption, oxygen permeability, electrical resistivity, chloride penetration and carbonation resistance were performed in the hardened state. The results revealed that the concrete mixes with recycled aggregate incorporated showed worse performance than the reference mixes. However, taking all the studied properties into account, it is possible to conclude that recycled aggregates from the precast concrete industry are of very good quality and can be incorporated in the production of SCC with ratios of $25 / 25 \%$ and $0 / 100 \%$ as recommended limits.

\section{Notation}

A top area of specimen $\left(\mathrm{m}^{2}\right)$

D flowmeter diameter (mm)

$D_{\text {nssm }} \quad$ non-steady-state migration coefficient $\left(\mathrm{m}^{2} / \mathrm{s}\right)$

$f_{\text {ad }} \quad$ supplementary cementitious materials ratio

I current intensity (A)

$K_{02} \quad$ concrete oxygen permeability $\left(\mathrm{m}^{2}\right)$

$L \quad$ thickness or length of specimen $(\mathrm{mm})$

$p \quad$ gas pressure inside specimen $(\mathrm{kPa})$

$Q \quad$ flow of air through specimen $\left(\mathrm{m}^{3} / \mathrm{s}\right)$

$S_{\mathrm{p}} / p_{\%} \quad$ percentage, in mass, of superplasticiser and fine materials in the mix

$T$ average value of initial and final temperatures in the anolyte solution $\left({ }^{\circ} \mathrm{C}\right)$

$t \quad$ test duration (h)

$t_{\mathrm{b}} \quad$ travel time of soap bubble (s)

$U \quad$ applied voltage (V)

$V_{\mathrm{m}} / V_{\mathrm{g}} \quad$ ratio, in absolute volume, between the mortar and coarse aggregate content

$V_{\mathrm{p}} / V_{\mathrm{s}} \quad$ ratio, in absolute volume, between the total amount of fine material (cement and additions) and fine aggregates

$V_{\mathrm{v}} \quad$ void volume

$V_{\mathrm{w}} / V_{\mathrm{p}} \quad$ ratio, in absolute volume, between the total content of water and fine materials

$x_{\mathrm{d}} \quad$ average penetration depth $(\mathrm{mm})$

$\rho \quad$ electrical resistivity of concrete $(\Omega . \mathrm{m})$

\section{Introduction}

Society's growing environmental awareness has led to greater concerns about the high consumption of natural resources and the waste generated by the activities of various industries. More specifically, the construction industry consumes a large proportion of these resources and is currently the main waste producer at European level (Fischer and Werge, 2009), the storage and treatment of which entails serious environmental and economic consequences.

Concrete is the most commonly used material in construction activities and is thus a major part of construction and demolition waste. In particular, due to its strict quality control, the structural precast industry produces large amounts of rejected concrete parts that, given their high quality, have great potential for recycling in new concrete. The use of such material would thus reduce both the consumption of natural resources necessary for the production of concrete and the amount of waste deposited in landfills.

Consequently, concrete technology requires a new approach based essentially on three vectors: $(a)$ production and placement methods with lower energy consumption, (b) increased durability of structures and $(c)$ higher recycling ratios of materials, in particular through their reintroduction (reuse) in the construction process. The use of self-compacting concrete (SCC) and the incorporation of recycled aggregates (RA) in the production of 
concrete and mortars are solutions with great potential, particularly for the precast industry, for which the final product requirements are greater. Therefore, the waste from this industry is also the one with the greatest potential to be used as high-quality RA in the production of new concrete elements.

Much work has been done on the study and characterisation of concrete produced with RA, including some using SCC. Among many other topics, researchers have studied the influence of RA on the fresh behaviour of SCC, the design methods of the mix proportions, the RA grinding process and the mechanical properties and durability in the hardened state. The following works can be highlighted.

Hansen and Boegh (1985) stated that the properties of RA are influenced by the quality of the source concrete, mainly due to the quality and quantity of mortar adhered to its surface. The mortar quality depends on the water/cement (w/c) ratio used in the source concrete and its quality depends on its strength and the grinding method used.

Nagatakia et al. (2004) concluded that the properties of coarse RA (CRA) are influenced by the grinding method and that further grinding processing gives rise to better quality RA. In close agreement, Matias et al. (2013) studied the influence of the grinding of natural aggregates (NA) and RA on concrete properties and concluded that RA have a more rounded shape than NA (evidenced by higher shape index values) due to the adhered mortar on RA.

Pereira-de-Oliveira et al. (2014) produced four types of SCC with different percentages $(0 \%, 20 \%, 40 \%$ and $60 \%)$ of coarse NA (CNA) replaced with CRA. They found that, in terms of mechanical behaviour (compressive and splitting tensile strengths and modulus of elasticity), the performance degradation was explained by the lower stiffness of CRA compared with CNA, given the presence of old adhered mortar in the CRA and also the greater deformability of the cement paste. In terms of durability, the authors pointed out that, in relation to oxygen permeability, SCC produced with RA can be considered hermetic. This was confirmed by water absorption tests performed on the same test specimens as the oxygen permeability test. The authors obtained relatively low water permeability values, ranging from $2.5 \times 10^{-18} \mathrm{~m}^{2}$ to $6 \cdot 0 \times 10^{-18} \mathrm{~m}^{2}$.

Modani and Mohitkar (2014) reported the production of six types of SCC with different percentages of CNA replacement with CRA (namely 0, 20, 40, 60, 80 and 100\%). They found that the incorporation of RA was responsible for a decrease of the concrete compressive strength due to the increase in the w/c ratio caused by the high water absorption and angular shape of the RA. Modani and Mohitkar (2014) also found that the capillary absorption increased with CRA content, explained by the higher water absorption capacity of the CRA compared with CNA. On the other hand, Pereira-deOliveira et al. (2014) found that the CRA content did not significantly affect the capillary absorption, but found that the capillary absorption decreased with the substitution of CNA with CRA. This was explained by the high volume of SCC cement paste, which surrounds the CRA and enters its porous structure.

It is also worth noting the work of Uygunoğlu et al. (2014), who studied SCCs made with CNA, CRA and aggregates from marble waste. They found that the SCC with CRA had greater ductility than the SCC made with CNA. For the same compressive strength, the SCC made with CRA showed greater deformability. The authors concluded that the nearcubic form and rougher surface of the RA retarded microcracking at the interface between the cement paste and the aggregate.

Other noteworthy works on the subjects noted in the previous paragraphs include the more recent and equally relevant studies conducted by Boudali et al. (2016), Güneyisi et al. (2016), Kapoor et al. (2016) and Manzi et al. (2017).

\section{Research objectives}

Although much work has already been done, there is still room for more research on this topic, namely on

- the characterisation of RA from the precast industry, as well as the need to use them

- the need to emphasise the advantages that SCC presents in terms of incorporation of RA due to the SCC composition - in-depth studies focusing on the use of fine RA (FRA)

- the feasibility of establishing acceptable maximum values for FRA incorporation

- the need to demystify the maximum allowed incorporation ratios of RA, which may well be increased by taking into account the quality of the RA to be used

- the feasibility of using RA in the production of structural concrete in order to make its application more general and to remove from users the idea that this material has no practical applicability.

Along this line of reasoning, the main objective of the work reported here was to provide the precast industry with an alternative way of eliminating and recovering self-generated waste, minimising the consumption of natural resources and, consequently, significantly reducing its environmental impact. In addition to the environmental aspects, there are also associated economic aspects related to the reduced costs of buying and transporting materials.

In this context, the research developed sought to deepen the knowledge on the properties of SCC made with RA. The study focused on the fine (FRA) and/or coarse (CRA) fraction of RA 
originating from precast industry concrete elements, at several incorporation ratios. The aim was to combine the advantages of using good-quality precast concrete waste with the technical, economic and environmental advantages of using SCC. The research also sought to demonstrate the applicability of such aggregates in SCC production, testing the influence of RA incorporation ratio on some aspects of its durability performance in order to obtain concrete with similar performance to that of the source concrete of the RA.

Based on the results, the possibility of using incorporation ratios of RA higher than those established in various regulations, both at national (LNEC, 2009) and international level (Gonçalves, 2007), was analysed. For this purpose, ten self-compacting mixes were produced, using RA to replace NA, in various FRA/CRA combinations, namely $0 / 0 \%, 25 / 25 \%, 50 / 50 \%, 0 / 100 \%$ and $100 / 0 \%$. This evaluation was made for two compressive strength classes of the source concrete of the RA (45 MPa and $65 \mathrm{MPa}$ ) with the intention of finally obtaining RA SCC with characteristics compatible with those of NA SCC in terms of overall performance. The mixes were evaluated in terms of their water absorption, capillary absorption, oxygen permeability, chloride penetration, electrical resistivity and carbonation.

\section{Experimental programme}

\section{Materials}

The following materials were used (further characterised in Figure 1 and Tables 1-3).

- Cement type CEM I $42.5 \mathrm{R}$ with a density of $3140 \mathrm{~kg} / \mathrm{m}^{3}$, complying with NP EN 197-1 (IPQ, 2008a).

- Two mineral additions - fly ash (FA) complying with NP EN 450-1 (IPQ, 2008b) and NP EN 450-2 (IPQ, 2006), with a density of $2300 \mathrm{~kg} / \mathrm{m}^{3}$, and limestone filler
(LF) complying with specification E466 (LNEC, 2005), with a density of $2720 \mathrm{~kg} / \mathrm{m}^{3}$.

- Two limestone coarse aggregates (CNA) complying with NP EN 12620 (IPQ, 2010a) (gravel 1 and gravel 2).

- Two siliceous sands (fine NA (FNA)) complying with NP EN 12620 (IPQ, 2010a) (one coarse (0/4) and one fine $(0 / 2))$.

- RA from crushed precast concrete elements of strength classes $45 \mathrm{MPa}$ and $65 \mathrm{MPa}$, designed to support very long beams; all fractions were used - one coarse CRA 65, one coarse CRA 45, one fine FRA 65 and one fine FRA 45.

- A third-generation modified polycarboxylate ether high-range water-reducing admixture complying with NP EN 934-1 (IPQ, 2008c) and NP EN 934-2 (IPQ, 2009) (in liquid form with a density of $1070 \mathrm{~kg} / \mathrm{m}^{3}$ ).

- Tap water complying with NP EN 1008 (IPQ, 2003).

The RA were separated according to their size by mechanical sieving, and all fractions were used so that the particle size distribution of the NA and RA was the same. Despite this, the grading curves of the NA and RA were different and therefore it was necessary to adjust the latter to match the former to equal the fineness modulus. To do this, it was necessary to separate the RA according to their particle sizes. Although this type of procedure is difficult for real-scale applications, it enables comparisons between mix compositions with the same particle size distribution and different replacement ratios.

\section{Mix proportions}

In order to cover the different variations of mixing quantities and the evaluation of PC 45 and PC 65 families, ten SCC mixes were produced according to NP EN 206-9 (IPQ, 2010b), as detailed in Table 4. The mixing contents used were obtained according to the method presented by Nepomuceno and

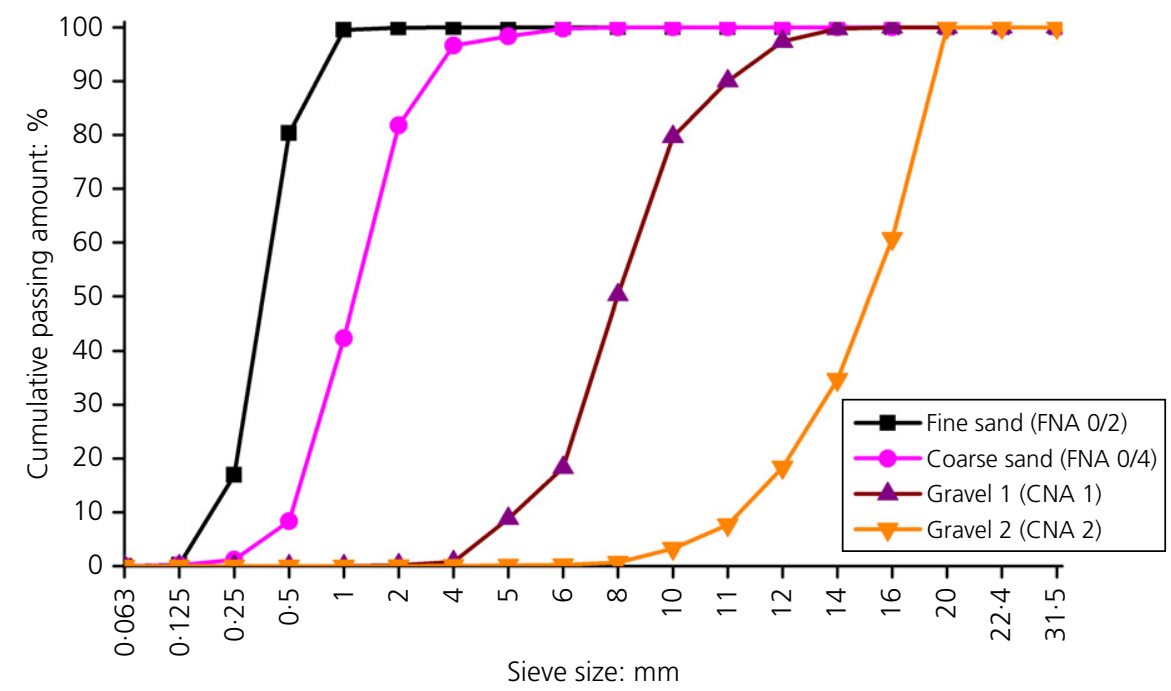

Figure 1. Particle size distributions of the aggregates 
Table 1. Chemical composition of raw materials (indicative values provided by suppliers)

$\begin{array}{lccc} & \text { CEM I } & \text { FA } & \text { LF } \\ \text { Aluminium oxide }\left(\mathrm{Al}_{2} \mathrm{O}_{3}\right): \% & 5.24 & 24.7 & 0.13 \\ \text { Calcium carbonate }\left(\mathrm{CaCO}_{3}\right) & - & - & 98.35 \\ \text { Calcium oxide }(\mathrm{CaO}): \% & 62.71 & 2.63 & - \\ \text { Chlorides }\left(\mathrm{Cl}^{-}\right) & 0.01 & <0.01 & - \\ \text { Ferric oxide }\left(\mathrm{Fe}_{2} \mathrm{O}_{3}\right): \% & 3.17 & 5.40 & 0.03 \\ \text { Potassium oxide }\left(\mathrm{K}_{2} \mathrm{O}\right): \% & - & 1.11 & 0.02 \\ \text { Magnesium oxide }(\mathrm{MgO}): \% & 2.23 & 1.01 & 0.40 \\ \text { Sodium oxide }\left(\mathrm{Na}_{2} \mathrm{O}\right): \% & - & 0.89 & - \\ \text { Silicon dioxide }\left(\mathrm{SiO}_{2}\right): \% & 19.59 & 54.70 & 0.30 \\ \text { Sulfur trioxide }\left(\mathrm{SO}_{3}\right): \% & 3.13 & 1.38 & - \\ \text { Titanium dioxide }\left(\mathrm{TiO}_{2}\right): \% & - & - & 0.01 \\ \text { Insoluble residue: \% } & 1.37 & - & - \\ \text { Loss on ignition: \% } & 2.94 & 5.10 & 43.80\end{array}$

Table 2. Grading of the raw materials (indicative values provided by producers)

\begin{tabular}{|c|c|c|c|}
\hline \multirow[b]{2}{*}{ Particle size: $\mu \mathrm{m}$} & \multicolumn{3}{|c|}{ Amount passing: \% } \\
\hline & CEM I & FA & LF \\
\hline 1000 & 100 & 100 & 100 \\
\hline 100 & 98 & 96 & 60 \\
\hline 10 & 38 & 45 & 20 \\
\hline 1 & 5 & 2 & 0 \\
\hline $0 \cdot 1$ & 0 & 0 & 0 \\
\hline
\end{tabular}

Oliveira (2008) and Nepomuceno et al. (2012), already used in several other applications (Bogas et al., 2012; Silva and de Brito, 2015; Silva et al., 2011).

The following composition parameters were considered

- The ratio, in absolute volume, between the total amounts of fine material (cement and additions) and fine aggregates in the mixes was $V_{\mathrm{p}} / V_{\mathrm{s}}=0 \cdot 80$.

- All concrete ternary mixes involved the use of LF and FA. For PC 45, the supplementary cementitious materials ratio $\left(f_{\text {ad }}\right)$ was $60 \%$, corresponding to $50 \%$ FA and $10 \%$ LF. For PC $65, f_{\text {ad }}$ was $35 \%$, corresponding to $30 \%$ FA and $5 \%$ LF.
The ratio between the water and fine material contents, in absolute volume $\left(V_{\mathrm{w}} / V_{\mathrm{p}}\right)$, and the percentage ratio between the superplasticiser and fine material contents, in weight $\left(S_{\mathrm{p}} / p_{\%}\right)$, were varied according to the need for water and superplasticiser in each mix.

- The void volume $\left(V_{\mathrm{v}}\right)$ was considered constant and equal to $0.03 \mathrm{~m}^{3}$, according to the method of Nepomuceno et al. (2012).

- The ratio between the mortar and coarse aggregate content in the mix, in absolute volume $\left(V_{\mathrm{m}} / V_{\mathrm{g}}\right)$, depended on the desired degree of self-compactability. This parameter was set at $2 \cdot 275$, according to the satisfactory results obtained by Silva and de Brito (2015).

\section{Test methods and sample preparation}

The test procedure used for the determination of the total volume of penetrable pores (water absorption) is described in specification E394 (LNEC, 1993a). This test was performed at 28, 91 and $182 \mathrm{~d}$ on three cubic specimens $(100 \times 100 \times 100 \mathrm{~mm})$ for each mix and age. Three values were obtained: $(a)$ the apparent mass of saturated samples after immersion until the increase in mass was less than $0 \cdot 1 \%,(b)$ the saturated surface dry mass and (c) the mass of dry samples (oven dried at $105 \pm 5^{\circ} \mathrm{C}$ to constant weight until the increase in mass was less than $0 \cdot 1 \%$ ).

The capillary absorption coefficient was calculated as the first derivative of the equation for the linear regression of the values corresponding to the first $6 \mathrm{~h}$ of capillary water absorption, as a function of the square root of time, determined according to specification E393 (LNEC, 1993b), at 28, 91 and $182 \mathrm{~d}$, using three cylindrical specimens (100 mm height and $150 \mathrm{~mm}$ diameter) for each mix and age. After a wet-curing period (temperature of $20 \pm 2^{\circ} \mathrm{C}$ and relative humidity $(\mathrm{RH}) \geq 95 \%$ ), the specimens were stored in a dry chamber at $40 \pm 5^{\circ} \mathrm{C}$ for $14 \mathrm{~d}$ until testing. The specimens were then placed in a water tray, duly supported. The inflow water was measured at pre-set times for the duration of the test $(72 \mathrm{~h})$.

Oxygen permeability was determined according to specification E392 (LNEC, 1993c), at 28, 91 and $182 \mathrm{~d}$, using three cylindrical specimens $(50 \mathrm{~mm}$ height and $150 \mathrm{~mm}$ diameter $)$ for each mix and age. Prior to testing, the specimens were

Table 3. NA and RA properties

$\begin{array}{lccccccc} & \begin{array}{c}\text { FNA } \\ \text { (sand 0/2) }\end{array} & \begin{array}{c}\text { FNA } \\ \text { (sand 0/4) }\end{array} & \begin{array}{c}\text { CNA } \\ \text { (gravel 1) }\end{array} & \begin{array}{c}\text { CNA } \\ \text { (gravel 2) }\end{array} & \text { FRA 45 } & \text { FRA 65 } & \text { CRA 45 } \\ \text { CRA 65 }\end{array}$


Table 4. Mix proportions and basic fresh-state properties of the SCCS

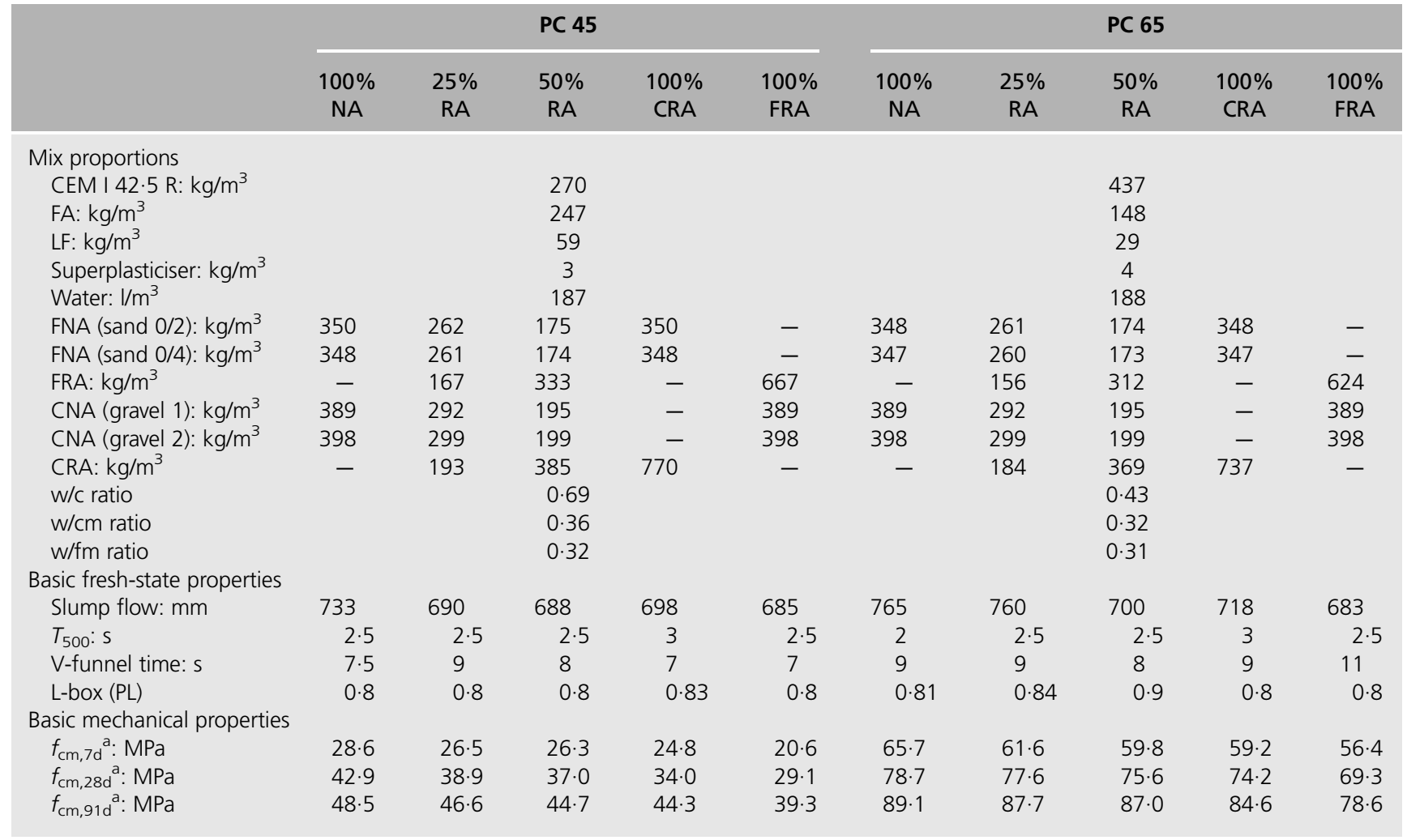

${ }^{\text {a }}$ Compressive strength of $15 \times 15 \times 15 \mathrm{~cm}$ cubes.

$\mathrm{w} / \mathrm{cm}$, water/cementitious materials; w/fm, water/fine materials

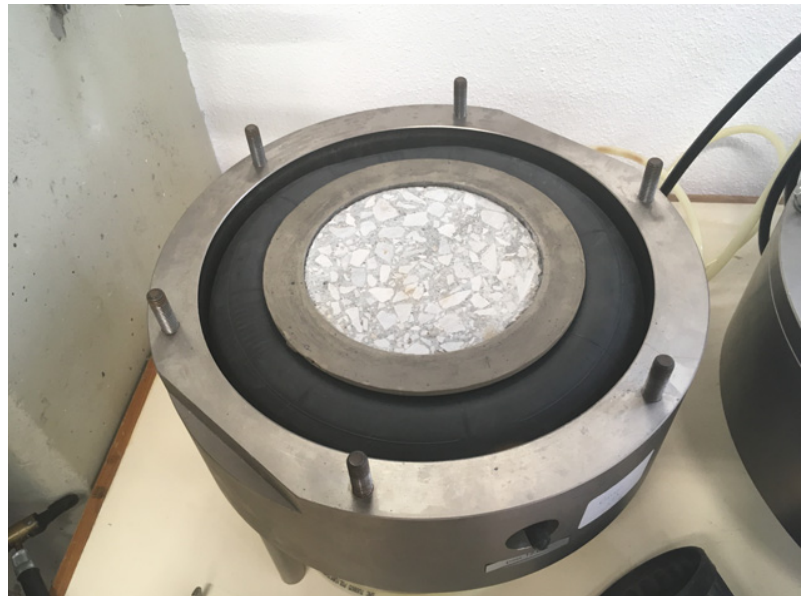

(a)

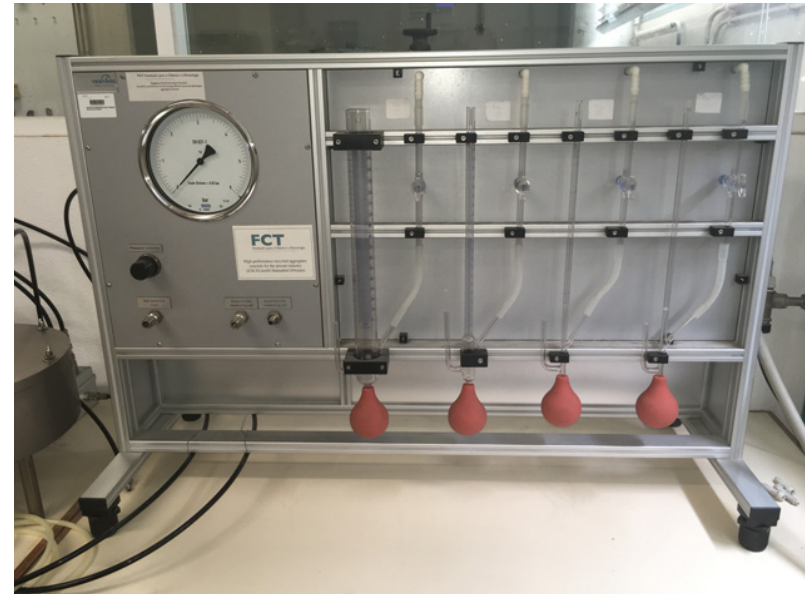

(b)

Figure 2. Oxygen permeability test: (a) specimens; (b) test setup

placed in a wet-curing chamber for the first $7 \mathrm{~d}$. Afterwards, they were dried in a ventilated oven at $40^{\circ} \mathrm{C}$ for $3 \mathrm{~d}$, wrapped in adherent film (so that no moisture changes occurred) and placed in a ventilated oven at $40^{\circ} \mathrm{C}$ for $17 \mathrm{~d}$. This preconditioning allowed for a uniform moisture distribution throughout the specimen. After the preconditioning process, the specimens were placed in chambers (Figure 2(a)) capable of withstanding pressures up to $5 \times 10^{-2} \mathrm{kN} / \mathrm{m}^{2}$. Three gas pressures $(p)$ inside the specimen were applied: 250,300 and $350 \mathrm{kPa}$. Flow readings were performed with flowmeters placed downstream, where the travel time of a soap bubble in the glass tube $\left(t_{\mathrm{b}}\right)$ was recorded (Figure 2(b)). The time that the bubble took to 
go through the flow tube was measured with a stopwatch and recorded.

The flow of air through the specimen $\left(Q\right.$ in $\left.\mathrm{m}^{3} / \mathrm{s}\right)$ was calculated using Equation 1, in which $D$ is the flowmeter diameter.

1. $Q=\frac{D}{t_{\mathrm{b}}}$

The concrete oxygen permeability (in $\mathrm{m}^{2}$ ) at a given pressure was calculated by Equation 2, in which $p_{1}=101200 \mathrm{~N} / \mathrm{m}^{2}$ and $p$ is the gas pressure inside the specimen.

2. $K_{\mathrm{O} 2}=\frac{1.14 \times 10^{-4} \times Q \times p_{1}}{p^{2}-p_{1}^{2}}$

The test procedure used to determine the chloride diffusion coefficient was that described in NT Build 492 (Nordtest, 1999) and E463 (LNEC, 2004). This test was performed at 28,91 and $182 \mathrm{~d}$ on three specimens $(\varnothing 100 \times 50 \mathrm{~mm})$ for each mix and age. After an adequate wet-curing time $\left(20^{\circ} \mathrm{C} \pm 2{ }^{\circ} \mathrm{C}\right.$ and $\left.\mathrm{RH} \geq 90 \%\right)$, the specimens were preconditioned in vacuum and immerged in a saturated calcium hydroxide $\left(\mathrm{Ca}(\mathrm{OH})_{2}\right)$ solution in distilled water. Afterwards, the specimens were connected to a rubber sleeve in order to contain an anodic solution of sodium hydroxide $(\mathrm{NaOH}$ $0 \cdot 3 \mathrm{~N}$ ) prepared with distilled water, without chlorides (Figure 3(a)). The rubber sleeve, with the specimen properly sealed as shown in Figure 3(a), was inserted in the sodium chloride $(\mathrm{NaCl})$ catholyte solution (solution at $10 \%$ sodium chloride mass in tap water). Then, an electric potential (according to point 6.4.4 in NT Build 492 (Nordtest, 1999) or E463 (LNEC, 2004)) was applied through the stainless steel plates on the top of the specimens, which forced the transportation of the chloride ions through the specimen by migration. After a given test period, the specimen was broken by axial splitting and the rectangular sections obtained were sprayed with a silver nitrate solution $\left(\mathrm{AgNO}_{3} 0 \cdot 1 \mathrm{~N}\right)$. The penetration depth was measured based on the visible white silver chloride precipitation. Using the penetration depth measurement obtained and other parameters, it was possible to calculate the chloride diffusion coefficient in the non-stationary regime $\left(D_{\text {nssm }}\right)$ from the simplified equation

3.

$$
\begin{aligned}
D_{\mathrm{nssm}}= & \frac{0.0239 \times(273+T) \times L}{(U-2) \times t} \\
& \times X_{\mathrm{d}}-0.0238 \times \sqrt{\frac{(273+T) \times L \times X_{\mathrm{d}}}{U-2}}
\end{aligned}
$$

in which $D_{\text {nssm }}$ is the non-steady-state migration coefficient $\left(\times 10^{-12} \mathrm{~m}^{2} / \mathrm{s}\right), U$ is the absolute value of the applied voltage (V), $T$ is the average value of the initial and final temperatures in the anolyte solution $\left({ }^{\circ} \mathrm{C}\right), L$ is the thickness of the specimen $(\mathrm{mm}), x_{\mathrm{d}}$ is the average value of the penetration depths $(\mathrm{mm})$ and $t$ is the test duration (h).

The test procedure used for determination of the electrical resistivity is described elsewhere (Durar, 2000; Luping, 2005; Polder, 2000). This test was performed at 28, 91 and $182 \mathrm{~d}$ on three $\varnothing 100 \times 50 \mathrm{~mm}$ specimens for each mix and age. After the wet-curing time $\left(20 \pm 2^{\circ} \mathrm{C}\right.$ and $\left.\mathrm{RH} \geq 95 \%\right)$, the specimens were preconditioned in vacuum and immersed in distilled water. Later, the saturated specimens were placed between two copper plaques with a $2 \mathrm{~kg}$ mass to compress the set (Figure 3(b)). Then, as shown in Figure 3(b), an electric potential of $60 \mathrm{~V}$ (DC) was applied through the copper plaques placed on the flat tops of the specimens and the value of the electrical current crossing the specimen was registered.

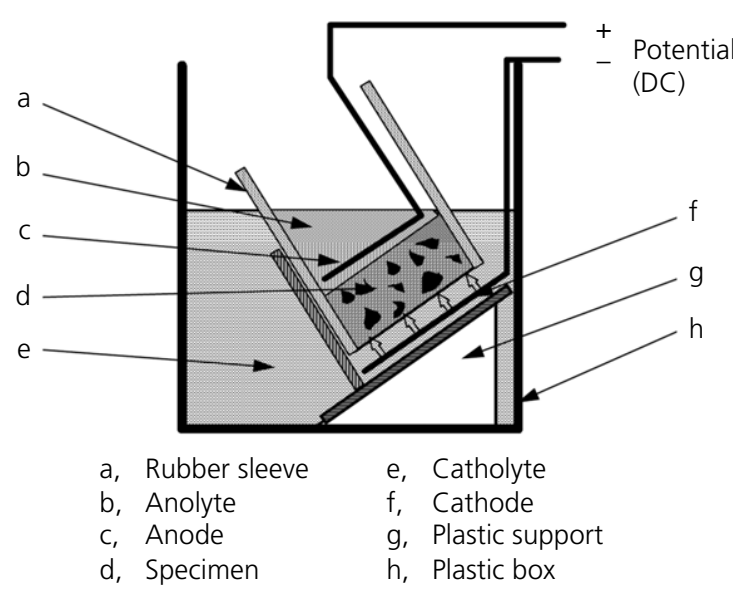

(a)

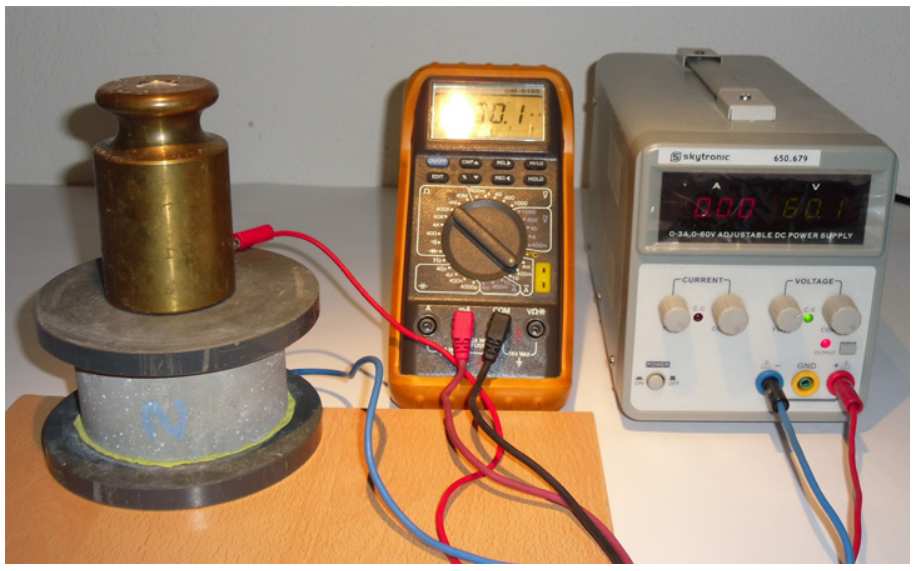

(b)

Figure 3. (a) Chloride migration test assembly scheme. (b) Electrical resistivity setup 
Table 5. Water absorption of PC 65 specimens (SD = standard deviation)

\begin{tabular}{|c|c|c|c|c|c|c|c|c|c|}
\hline \multirow[b]{2}{*}{ Mix } & \multicolumn{3}{|c|}{$28 \mathrm{~d}$} & \multicolumn{3}{|c|}{$91 \mathrm{~d}$} & \multicolumn{3}{|c|}{$182 d$} \\
\hline & $\begin{array}{c}\text { Water } \\
\text { absorption: \% }\end{array}$ & SD: $\%$ & $\Delta_{100 \% \text { NA }}: \%$ & $\begin{array}{c}\text { Water } \\
\text { absorption: \% }\end{array}$ & SD: $\%$ & $\Delta_{100 \% \text { NA }}: \%$ & $\begin{array}{c}\text { Water } \\
\text { absorption: \% }\end{array}$ & SD: $\%$ & $\Delta_{100 \% \text { NA }}: \%$ \\
\hline $100 \%$ NA & $12 \cdot 5$ & 0.1 & 0.0 & $12 \cdot 2$ & 0.4 & 0.0 & $11 \cdot 8$ & 0.3 & 0.0 \\
\hline $25 \%$ RA & $15 \cdot 2$ & $0 \cdot 1$ & $21 \cdot 3$ & $15 \cdot 0$ & 0.1 & $22 \cdot 5$ & 14.9 & 0.1 & $26 \cdot 4$ \\
\hline $50 \%$ RA & $17 \cdot 1$ & 0.0 & $36 \cdot 3$ & $16 \cdot 6$ & 0.3 & $36 \cdot 0$ & $16 \cdot 1$ & 0.2 & $37 \cdot 3$ \\
\hline $100 \%$ CRA & $15 \cdot 6$ & 0.1 & $24 \cdot 6$ & $15 \cdot 6$ & 0.0 & $27 \cdot 5$ & $14 \cdot 9$ & 0.4 & $27 \cdot 0$ \\
\hline $100 \%$ FRA & $17 \cdot 7$ & 0.9 & $41 \cdot 4$ & $17 \cdot 3$ & 0.1 & $41 \cdot 7$ & $16 \cdot 8$ & $0 \cdot 1$ & $42 \cdot 5$ \\
\hline
\end{tabular}

Table 6. Water absorption of PC 45 specimens

\begin{tabular}{|c|c|c|c|c|c|c|c|c|c|}
\hline \multirow[b]{2}{*}{ Mix } & \multicolumn{3}{|c|}{$28 d$} & \multicolumn{3}{|c|}{$91 \mathrm{~d}$} & \multicolumn{3}{|c|}{$182 \mathrm{~d}$} \\
\hline & $\begin{array}{c}\text { Water } \\
\text { absorption: \% }\end{array}$ & SD: $\%$ & $\Delta_{100 \% \mathrm{NA}}: \%$ & $\begin{array}{c}\text { Water } \\
\text { absorption: \% }\end{array}$ & SD: $\%$ & $\Delta_{100 \% \mathrm{NA}}: \%$ & $\begin{array}{c}\text { Water } \\
\text { absorption: \% }\end{array}$ & SD: $\%$ & $\Delta_{100 \% \mathrm{NA}}: \%$ \\
\hline $100 \%$ NA & $15 \cdot 5$ & 0.2 & 0.0 & $14 \cdot 6$ & 0.2 & 0.0 & $14 \cdot 2$ & 0.2 & 0.0 \\
\hline $25 \%$ RA & $16 \cdot 1$ & 0.6 & $3 \cdot 9$ & $15 \cdot 7$ & 0.6 & $7 \cdot 5$ & $15 \cdot 2$ & 0.6 & $7 \cdot 3$ \\
\hline $50 \%$ RA & $17 \cdot 1$ & 0.6 & $10 \cdot 7$ & $16 \cdot 5$ & 0.5 & $13 \cdot 1$ & $16 \cdot 4$ & 0.3 & $16 \cdot 1$ \\
\hline $100 \%$ CRA & $16 \cdot 2$ & 0.5 & $4 \cdot 7$ & $15 \cdot 8$ & 0.4 & $8 \cdot 5$ & $15 \cdot 6$ & 0.2 & $10 \cdot 4$ \\
\hline $100 \%$ FRA & $18 \cdot 3$ & 0.1 & $18 \cdot 4$ & $18 \cdot 2$ & 0.5 & $24 \cdot 8$ & $18 \cdot 1$ & 0.3 & $27 \cdot 8$ \\
\hline
\end{tabular}

It was thus possible to calculate the electrical resistivity from Equation 4, in which $\rho$ is the concrete's electrical resistivity $(\Omega . \mathrm{m}), U$ is the applied voltage $(\mathrm{V}), I$ is the current intensity (A), $A$ is the top area of the specimen $\left(\mathrm{m}^{2}\right)$ and $L$ is the length of the specimen $(\mathrm{m})$.

4. $\rho=\frac{U}{I} \times \frac{A}{L}$

The test procedure used for determination of the carbonation resistance is described in specification E391 (LNEC, 1993d) and Rilem CPC-18 (Rilem, 1988). A $\varnothing 100 \times 50 \mathrm{~mm}$ specimen of each mix was tested at each of the five ages $(7,28,56,91$ and $182 \mathrm{~d}$ ) of exposure in the carbon dioxide chamber. All the specimens were subjected to water curing at $20 \pm 2^{\circ} \mathrm{C}$ until $14 \mathrm{~d}$ prior to the start of the test (i.e. being placed in the carbonation chamber). The specimens were then preconditioned at $20 \pm 2{ }^{\circ} \mathrm{C}$ and $50 \% \mathrm{RH}$ until they were placed in the carbonation chamber (at $28 \mathrm{~d}$ ). The chamber had $5 \pm 1 \%$ of carbon dioxide and was held at $60 \pm 5 \% \mathrm{RH}$ and $23 \pm 3^{\circ} \mathrm{C}$. After 7, 28, 56, 91 and $182 \mathrm{~d}$ of exposure, the specimens were removed from the chamber and sectioned. The carbonation depth was then measured using a colorimetric method $(0 \cdot 1 \%$ phenolphthalein).

\section{Test results and discussion}

Water absorption

Tables 5 and 6 and Figures 4 and 5 show the water absorption results for both SCC families (PC 65 and PC 45).

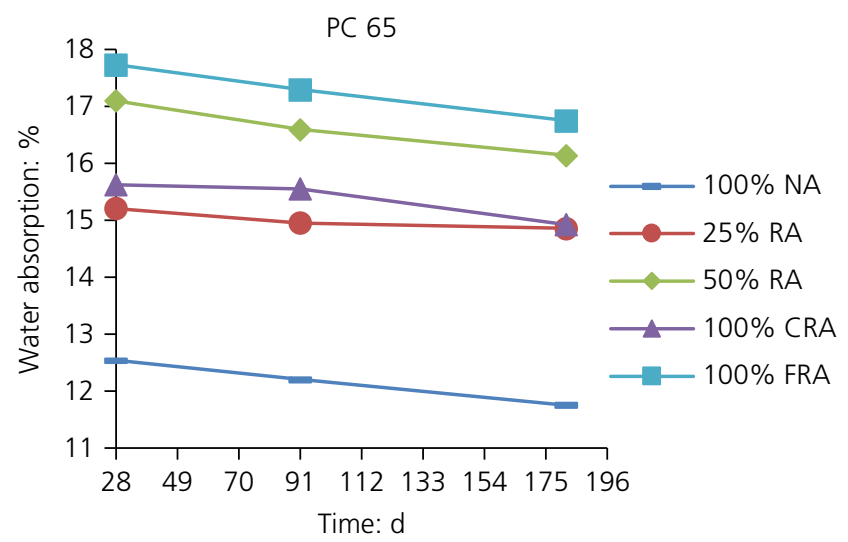

Figure 4. Water absorption at 28, 91 and $182 \mathrm{~d}$ (PC 65)

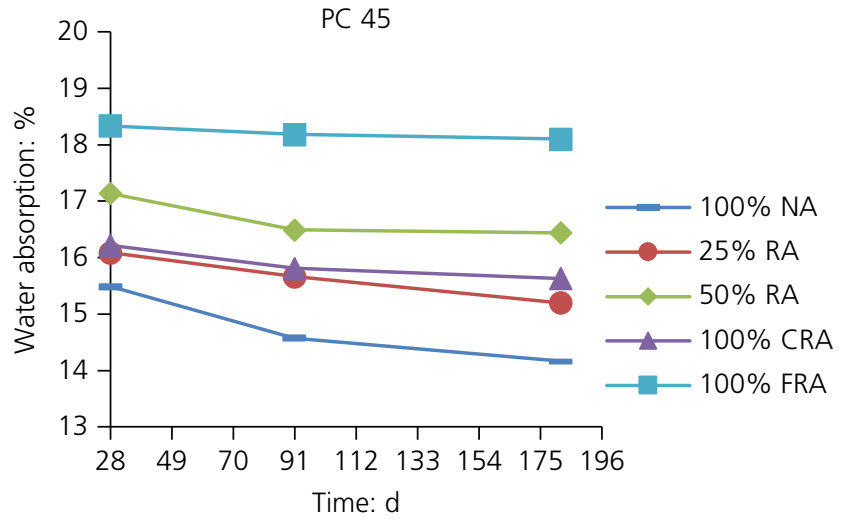

Figure 5. Water absorption at 28, 91 and $182 \mathrm{~d}$ (PC 45) 
Table 7. 28, 91 and 182 d capillary water absorption at $72 \mathrm{~h}$ for PC 65

\begin{tabular}{|c|c|c|c|c|c|c|c|c|c|}
\hline \multirow[b]{2}{*}{ Mix } & \multicolumn{3}{|c|}{$28 \mathrm{~d}$} & \multicolumn{3}{|c|}{$91 \mathrm{~d}$} & \multicolumn{3}{|c|}{$182 \mathrm{~d}$} \\
\hline & $\begin{array}{c}\text { Capillary } \\
\text { absorption: } \mathrm{kg} / \mathrm{m}^{2}\end{array}$ & $\begin{array}{l}\mathrm{SD}: \\
\mathrm{kg} / \mathrm{m}^{2}\end{array}$ & $\begin{array}{c}\Delta_{100 \% \mathrm{NA}}: \\
\%\end{array}$ & $\begin{array}{c}\text { Capillary } \\
\text { absorption: } \mathrm{kg} / \mathrm{m}^{2}\end{array}$ & $\begin{array}{l}\text { SD: } \\
\mathrm{kg} / \mathrm{m}^{2}\end{array}$ & $\begin{array}{c}\Delta_{100 \% \mathrm{NA}}: \\
\%\end{array}$ & $\begin{array}{c}\text { Capillary } \\
\text { absorption: } \mathrm{kg} / \mathrm{m}^{2}\end{array}$ & $\begin{array}{l}\mathrm{SD}: \\
\mathrm{kg} / \mathrm{m}^{2}\end{array}$ & $\begin{array}{c}\Delta_{100 \% \mathrm{NA}}: \\
\%\end{array}$ \\
\hline $100 \%$ NA & 0.98 & $0 \cdot 13$ & 0.0 & $0 \cdot 37$ & 0.04 & $0 \cdot 0$ & 0.22 & 0.02 & 0.0 \\
\hline $25 \%$ RA & 1.09 & 0.08 & $11 \cdot 2$ & $0 \cdot 40$ & 0.02 & 8.0 & 0.23 & 0.03 & $7 \cdot 4$ \\
\hline $50 \%$ RA & $1 \cdot 30$ & 0.04 & $33 \cdot 2$ & 0.46 & 0.06 & $26 \cdot 4$ & $0 \cdot 31$ & 0.07 & $45 \cdot 5$ \\
\hline $100 \%$ CRA & 1.25 & 0.09 & $28 \cdot 0$ & 0.41 & 0.02 & $11 \cdot 2$ & 0.28 & 0.01 & $29 \cdot 7$ \\
\hline $100 \%$ FRA & $1 \cdot 38$ & $0 \cdot 14$ & $41 \cdot 1$ & 0.49 & 0.02 & $33 \cdot 0$ & 0.32 & 0.02 & $47 \cdot 8$ \\
\hline
\end{tabular}

Table 8. 28, 91 and $182 \mathrm{~d}$ capillary water absorption at $72 \mathrm{~h}$ for PC 45

\begin{tabular}{|c|c|c|c|c|c|c|c|c|c|}
\hline \multirow[b]{2}{*}{ Mix } & \multicolumn{3}{|c|}{$28 d$} & \multicolumn{3}{|c|}{$91 \mathrm{~d}$} & \multicolumn{3}{|c|}{$182 d$} \\
\hline & $\begin{array}{l}\text { Capillary } \\
\text { absorption: } \mathrm{kg} / \mathrm{m}^{2}\end{array}$ & $\begin{array}{c}\mathrm{SD}: \\
\mathrm{kg} / \mathrm{m}^{2}\end{array}$ & $\Delta_{100 \% \mathrm{NA}}: \%$ & $\begin{array}{l}\text { Capillary } \\
\text { absorption kg/m² }\end{array}$ & $\begin{array}{c}\mathrm{SD}: \\
\mathrm{kg} / \mathrm{m}^{2}\end{array}$ & $\Delta_{100 \% \mathrm{NA}}: \%$ & $\begin{array}{l}\text { Capillary } \\
\text { absorption kg/m² }\end{array}$ & $\begin{array}{c}\mathrm{SD}: \\
\mathrm{kg} / \mathrm{m}^{2}\end{array}$ & $\Delta_{100 \% \mathrm{NA}}: \%$ \\
\hline $100 \%$ NA & $2 \cdot 28$ & 0.10 & 0.0 & 1.00 & 0.15 & 0.0 & 0.64 & 0.06 & 0.0 \\
\hline $25 \%$ RA & $2 \cdot 59$ & 0.16 & $13 \cdot 3$ & 1.08 & 0.08 & $8 \cdot 1$ & 0.66 & 0.04 & $2 \cdot 5$ \\
\hline $50 \%$ RA & $2 \cdot 90$ & 0.48 & $26 \cdot 8$ & $1 \cdot 14$ & 0.22 & $14 \cdot 2$ & 0.72 & 0.08 & $12 \cdot 2$ \\
\hline $100 \%$ CRA & $2 \cdot 85$ & 0.28 & $24 \cdot 7$ & $1 \cdot 11$ & 0.25 & $11 \cdot 1$ & 0.71 & 0.03 & $10 \cdot 2$ \\
\hline $100 \%$ FRA & 3.03 & 0.35 & $32 \cdot 7$ & $1 \cdot 19$ & $0 \cdot 10$ & $19 \cdot 5$ & 0.77 & 0.12 & $19 \cdot 8$ \\
\hline
\end{tabular}

It was found that the SCC with $100 \%$ FRA registered the greatest water absorption. In the PC 65 family, the variation, relative to the reference SCC (100\% NA), was approximately $42 \%$ at all ages. In the PC 45 family, there were variations of $18 \%, 25 \%$ and $28 \%$ at 28,91 and $182 \mathrm{~d}$, respectively. The small variation of this property over time leads to the conclusion that the open pores, accessible to the exterior and responsible for the absorption, did not experience much change with age.

It was also observed that the SCC with $100 \%$ CRA (i.e. substitution only with coarse RA) had a lower water absorption than the SCC with 50\% RA (50\% fine and coarse RA). This is because CRA have a much lower water absorption than FRA, which are conditioning factors in this property.

The observed increase in water absorption in the SCC mixes with $100 \%$ CRA can be confirmed, for example, by the work of Grdic et al. (2010): these authors found a $67 \%$ increase in the $100 \%$ CRA mix and explained this by the greater absorption of the RA relative to that of the NA and the gradual increase of the $\mathrm{w} / \mathrm{c}$ ratio of the produced mixes $(\mathrm{w} / \mathrm{c}=0.41$ for SCC with $100 \%$ NA and w/c $=0.45$ for SCC with $100 \%$ CRA). Gómez-Soberón (2002) stated that the presence of old mortar adhered to RA is responsible for the greater porosity and absorption of the RA, which significantly affects the open porosity of concrete made with RA.

\section{Capillary absorption}

Tables 7 and 8 and Figures 6 and 7 show the capillary absorption results for both SCC families (PC 65 and PC 45). Only

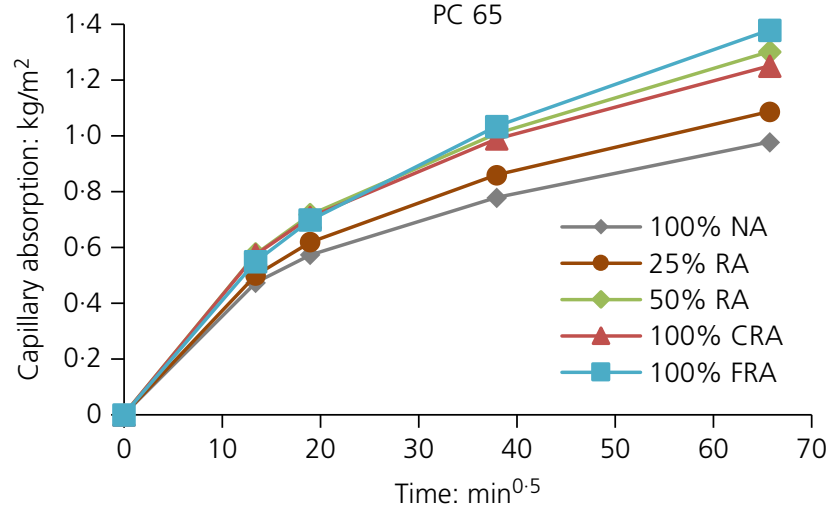

Figure 6. 28 d capillary water absorption for PC 65

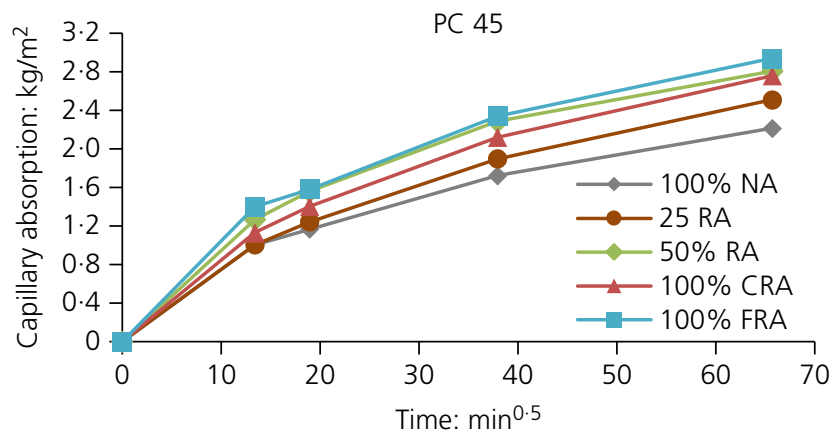

Figure 7. 28 d capillary water absorption for PC 45 
the results obtained at $28 \mathrm{~d}$ are presented in Figures 6 and 7 since the trends observed at 28,91 and $182 \mathrm{~d}$ were the same.

Figures 6 and 7 show that capillary absorption occurred more intensely in the early stage (i.e. the greatest slope in the first section of the graphs). In addition, the PC 65 mixes exhibited significantly better results than the PC 45 mixes.

Tables 7 and 8 show a decrease in capillary absorption with concrete age, which can be explained by the decrease in the size of capillary pores. The incorporation of FA causes an increase in the mean pore size at younger ages. However, for more advanced ages, the pore volume tends to decrease, reducing the possibility of water penetration (Rilem, 1999).

It was found that the SCC with 100\% FRA registered the greatest capillary water absorption. The variation from the reference SCC at $28 \mathrm{~d}$ was $41 \%$ for the PC 65 family and $33 \%$ for the PC 45 family. Modani and Mohitkar (2014) found the same trend, obtaining an increase of $41 \%$ for a mix with $100 \%$ CRA at $28 \mathrm{~d}$.

The results can be explained by the higher porosity of RA compared with NA, due to the old mortar adhered to RA. Wirquin et al. (2000) reported that the presence of RA in concrete is responsible for the formation of more and larger capillary pores.

It was also observed that, as in the water absorption test, the SCC made with $100 \%$ CRA showed lower capillary absorption values than the SCC made with 50\% RA, because CRA have much lower absorption values than FRA, which is relevant for this capillarity.

Figures 8 and 9 show the relationships between capillary absorption and water absorption and compressive strength, respectively (only the results from the PC 45 family are presented). It was found that water absorption and capillarity varied linearly, decreasing with age. A strong correlation was found between capillary absorption and compressive strength, which varied inversely: the capillary absorption increased with a decrease in the quality of the concrete (interpreted from the reduced compressive strength).

\section{Oxygen permeability}

Tables 9 and 10 and Figures 10 and 11 show the oxygen permeability results for both SCC families. It was not possible to obtain results for this test at $182 \mathrm{~d}$ of age (the test specimens remained inside the test chamber and no oxygen passage was observed after $24 \mathrm{~h}$ ), so only the results at $28 \mathrm{~d}$ and $91 \mathrm{~d}$ are presented.

The oxygen permeability was found to increase with the substitution of NA with RA due to old adhered mortar on the

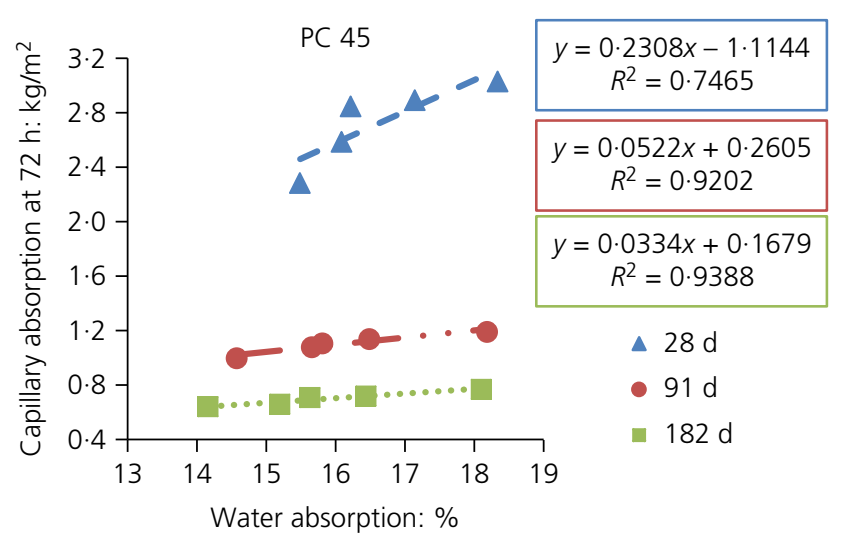

Figure 8. 28, 91 and $182 \mathrm{~d}$ capillary absorption (at $72 \mathrm{~h}$ ) plotted against water absorption for PC 45

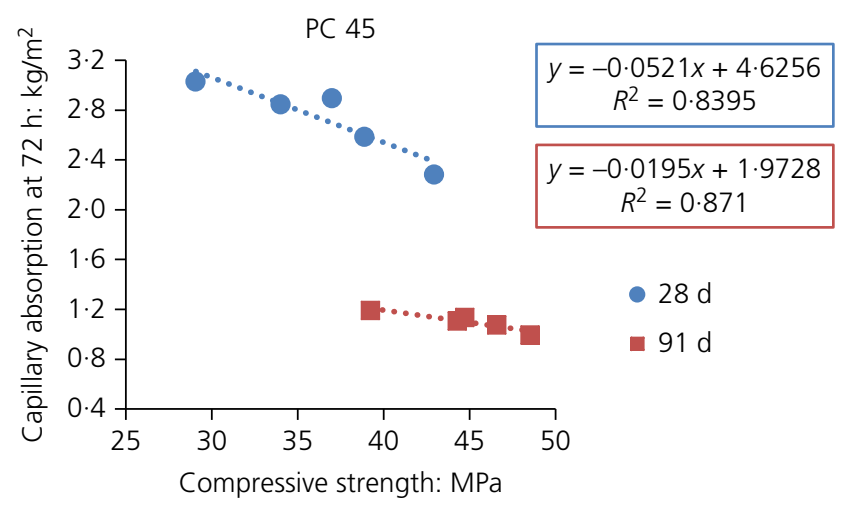

Figure 9. 28, 91 and 182 d capillary absorption (at 72 h) plotted against compressive strength for PC 45

RA, which increases their porosity and, consequently, that of the concrete. The most oxygen-permeable mixes were those with $100 \%$ FRA, with very high variations relative to the reference SCC: an increase of about $670 \%$ for the PC 65 family and $520 \%$ for the PC 45 family at $28 \mathrm{~d}$. The mixes with $50 \%$ RA showed increases of $433 \%$ (PC 65) and 240\% (PC 45) at 28 d. Zong et al. (2014) obtained increases of $225 \%$ for conventional concrete with the same RA incorporation ratio. Pereira-de-Oliveira et al. (2014) were unable to obtain oxygen permeability values and therefore considered that the SCCs were hermetic relative to this property.

A very pronounced reduction in oxygen permeability with concrete age was also observed due to the presence of FA. At an early age, the effect of RA on concrete is relevant; however, with increasing age, FA begins to react and its effect overlaps the effect of RA (Camões, 2002). The pozzolanic reaction of FA with the products resulting from the hydration of cement is responsible for the filling of pores in the concrete, thus hindering the penetration of oxygen. This was also confirmed by the capillary absorption test results. 
Table 9. Oxygen permeability (PC 65)

\begin{tabular}{|c|c|c|c|c|c|c|}
\hline \multirow[b]{2}{*}{ Mix } & \multicolumn{3}{|c|}{$28 d$} & \multicolumn{3}{|c|}{$91 \mathrm{~d}$} \\
\hline & $\begin{array}{l}\text { Oxygen permeability: } \\
\qquad 10^{-16} \mathrm{~m}^{2}\end{array}$ & SD: $10^{-16} \mathrm{~m}^{2}$ & $\Delta_{100 \% \text { NA }}: \%$ & $\begin{array}{l}\text { Oxygen permeability: } \\
\qquad 10^{-16} \mathrm{~m}^{2}\end{array}$ & SD: $10^{-16} \mathrm{~m}^{2}$ & $\Delta_{100 \% \mathrm{NA}}: \%$ \\
\hline $100 \%$ NA & 0.42 & 0.23 & 0.0 & 0.035 & 0.003 & 0.0 \\
\hline $25 \%$ RA & 0.59 & 0.21 & $42 \cdot 4$ & 0.072 & 0.032 & $107 \cdot 7$ \\
\hline $50 \%$ RA & $2 \cdot 21$ & $0 \cdot 37$ & $432 \cdot 5$ & 0.33 & $0 \cdot 160$ & $849 \cdot 1$ \\
\hline $100 \%$ CRA & 0.83 & $0 \cdot 17$ & 98.5 & 0.22 & 0.082 & $536 \cdot 5$ \\
\hline $100 \%$ FRA & $3 \cdot 20$ & $0 \cdot 38$ & $668 \cdot 8$ & 0.48 & 0.086 & $1280 \cdot 8$ \\
\hline
\end{tabular}

Table 10. Oxygen permeability (PC 45)

\begin{tabular}{|c|c|c|c|c|c|c|}
\hline \multirow[b]{2}{*}{ Mix } & \multicolumn{3}{|c|}{$28 \mathrm{~d}$} & \multicolumn{3}{|c|}{$91 \mathrm{~d}$} \\
\hline & $\begin{array}{l}\text { Oxygen permeability: } \\
\qquad 10^{-16} \mathrm{~m}^{2}\end{array}$ & SD: $10^{-16} \mathrm{~m}^{2}$ & $\Delta_{100 \% \text { NA }}: \%$ & $\begin{array}{l}\text { Oxygen permeability: } \\
\qquad 10^{-16} \mathrm{~m}^{2}\end{array}$ & SD: $10^{-16} \mathrm{~m}^{2}$ & $\Delta_{100 \% \text { NA }}: \%$ \\
\hline $100 \%$ NA & $5 \cdot 10$ & $4 \cdot 19$ & 0.0 & $1 \cdot 26$ & 0.076 & 0.0 \\
\hline $25 \%$ RA & $7 \cdot 16$ & $12 \cdot 10$ & $40 \cdot 5$ & $2 \cdot 62$ & $1 \cdot 00$ & $107 \cdot 5$ \\
\hline $50 \%$ RA & $17 \cdot 3$ & $22 \cdot 20$ & $240 \cdot 3$ & 5.04 & $2 \cdot 31$ & $299 \cdot 1$ \\
\hline $100 \%$ CRA & $14 \cdot 2$ & $9 \cdot 76$ & 178.0 & $3 \cdot 35$ & $1 \cdot 33$ & $165 \cdot 2$ \\
\hline $100 \%$ FRA & 31.5 & $28 \cdot 70$ & $518 \cdot 0$ & $9 \cdot 96$ & 0.59 & $688 \cdot 7$ \\
\hline
\end{tabular}

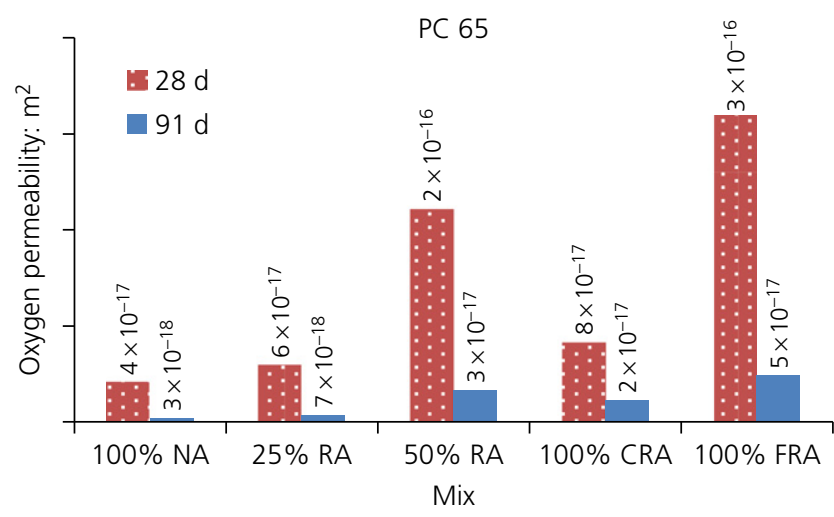

Figure 10. 28 and $91 \mathrm{~d}$ oxygen permeability (PC 65)

According to the Rilem TC 116-PCD classification (Rilem, 1999), at $91 \mathrm{~d}$, all mixes in the PC 65 family had good resistance to oxygen penetration (all results below $0.5 \times 10^{-16} \mathrm{~m}^{2}$ ). For the PF 45 family, at $91 \mathrm{~d}$, only the $100 \%$ NA concrete presented moderate resistance to oxygen penetration (results in the range 0.5 to $2 \cdot 5 \times 10^{-16} \mathrm{~m}^{2}$ ). The other mixes showed low resistance to oxygen penetration (results in the range 2.5 to $\left.12.5 \times 10^{-16} \mathrm{~m}^{2}\right)$.

Figures 12 and 13 show strong relationships between oxygen permeability and the other transport mechanisms, namely water absorption and capillarity (the relationships are presented only for the PC 45 family).

By correlating oxygen permeability with water absorption, correlation coefficients of 0.94 and 0.97 were obtained at 28 and

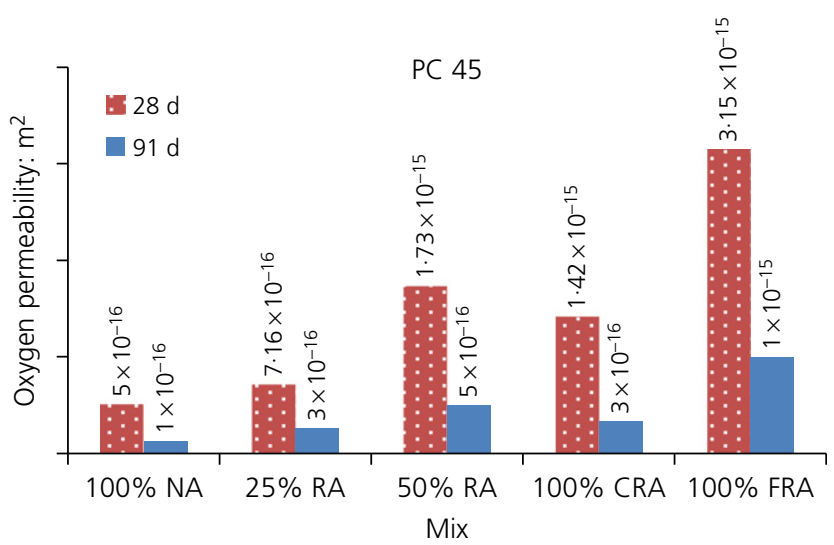

Figure 11.28 and $91 \mathrm{~d}$ oxygen permeability (PC 45)

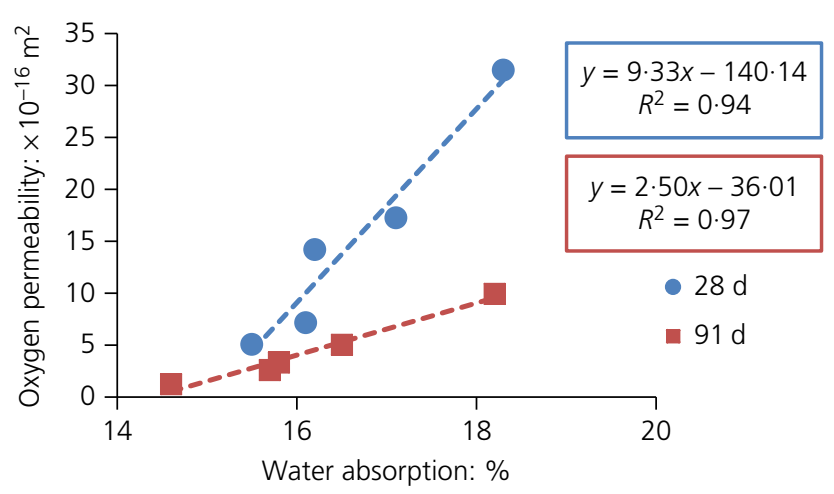

Figure 12. Oxygen permeability plotted against water absorption for PC 45 


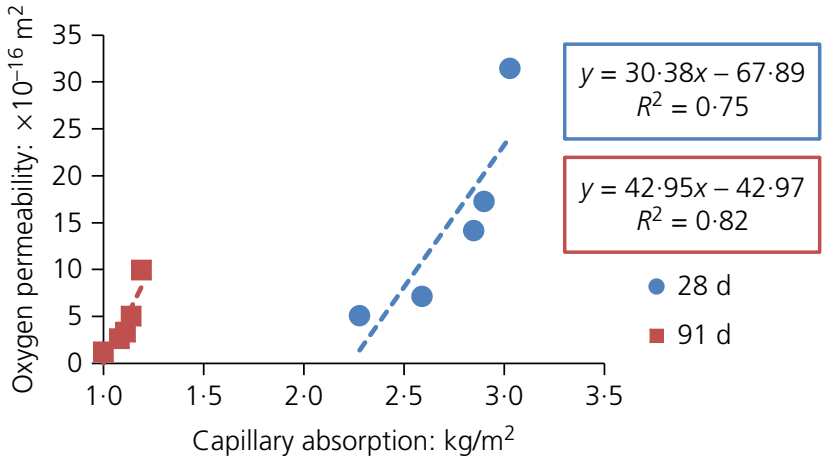

Figure 13. Oxygen permeability plotted against capillary absorption for PC 45

$91 \mathrm{~d}$, respectively (Figure 12). Relating oxygen permeability to capillary absorption, correlation coefficients of 0.75 and 0.82 were obtained at 28 and $91 \mathrm{~d}$, respectively (Figure 13).

\section{Chloride migration test}

Tables 11 and 12 and Figures 14 and 15 show the results of the chloride migration test for both SCC families. The chloride resistance was found to increase with the age of the concrete and to decrease with the incorporation of FRA. The highest chloride penetration occurred in the $100 \%$ FRA mixes, with an increase of $69 \%$ (PC 65) and $42 \%$ (PC 45) relative to the reference $\mathrm{SCC}$ at $28 \mathrm{~d}$. This can be explained by the poor quality of the SCC mortar (due to the substitution of sand with FRA) since ion transport is preferentially carried out in this medium. Tuyan et al. (2014) found the same trend in their study, in which the resistance to chloride ion penetration decreased with the CRA content (i.e. the penetration of chloride ions increased with CRA content). This was justified by the authors by the greater porosity of CRA compared with CNA.

Figures 16 and 17 show the correlations between chloride migration coefficient and water absorption and capillarity; only the results from the PC 45 family are shown.

\section{Electrical resistivity}

Tables 13 and 14 and Figures 18 and 19 show the electrical resistivity results for both SCC families. It was found that the electrical resistivity decreased with the substitution of NA with RA. The $100 \%$ FRA mixes showed the worst performance in both families, with reductions of $46 \%$ (PC 65) and 66\% (PC 45) in relation to the reference SCC at 28 d. Surya et al. (2013) obtained reductions of $33 \%$ when comparing a reference concrete with mixes in which only RA were used. This was justified by the higher porosity of RA compared with NA, due to the old adhered mortar of the RA.

Figures 20 and 21 show the relationship between electrical resistivity and chloride migration coefficient for the PC 65 and

Table 11. Chloride non-steady-state migration coefficients (PC 65)

\begin{tabular}{|c|c|c|c|c|c|c|c|c|c|}
\hline \multirow[b]{2}{*}{ Mix } & \multicolumn{3}{|c|}{$28 d$} & \multicolumn{3}{|c|}{$91 \mathrm{~d}$} & \multicolumn{3}{|c|}{$182 \mathrm{~d}$} \\
\hline & $\begin{array}{l}\text { Chloride } \\
\text { migration } \\
\text { coefficient: } \\
\times 10^{-12} \mathrm{~m}^{2} / \mathrm{s}\end{array}$ & $\begin{array}{c}\text { SD: } \\
\times 10^{-12} \mathrm{~m}^{2} / \mathrm{s}\end{array}$ & $\begin{array}{c}\Delta_{100 \% \mathrm{NA}}: \\
\%\end{array}$ & $\begin{array}{l}\text { Chloride } \\
\text { migration } \\
\text { coefficient: } \\
\times 10^{-12} \mathrm{~m}^{2} / \mathrm{s}\end{array}$ & $\begin{array}{c}\text { SD: } \\
\times 10^{-12} \mathrm{~m}^{2} / \mathrm{s}\end{array}$ & $\begin{array}{c}\Delta_{100 \% \text { NA }}: \\
\%\end{array}$ & $\begin{array}{l}\text { Chloride } \\
\text { migration } \\
\text { coefficient: } \\
\times 10^{-12} \mathrm{~m}^{2} / \mathrm{s}\end{array}$ & $\begin{array}{c}\text { SD: } \\
\times 10^{-12} \mathrm{~m}^{2} / \mathrm{s}\end{array}$ & $\begin{array}{c}\Delta_{100 \% \mathrm{NA}}: \\
\%\end{array}$ \\
\hline $100 \%$ NA & $5 \cdot 5$ & 0.38 & $0 \cdot 0$ & $2 \cdot 7$ & 0.37 & $0 \cdot 0$ & $2 \cdot 4$ & 0.69 & 0.0 \\
\hline $25 \%$ RA & $6 \cdot 3$ & 0.01 & $15 \cdot 7$ & $3 \cdot 5$ & 0.14 & $29 \cdot 7$ & $3 \cdot 1$ & 0.12 & $31 \cdot 7$ \\
\hline $50 \%$ RA & $8 \cdot 0$ & $1 \cdot 22$ & $46 \cdot 6$ & $4 \cdot 3$ & 0.36 & $60 \cdot 4$ & $3 \cdot 8$ & 0.03 & $58 \cdot 3$ \\
\hline $100 \%$ CRA & $5 \cdot 7$ & 0.19 & $5 \cdot 0$ & $3 \cdot 2$ & 0.33 & $20 \cdot 5$ & $2 \cdot 9$ & 0.03 & $22 \cdot 6$ \\
\hline $100 \%$ FRA & $9 \cdot 2$ & 0.17 & $68 \cdot 9$ & $4 \cdot 8$ & 0.68 & 78.6 & $4 \cdot 1$ & 0.15 & $70 \cdot 0$ \\
\hline
\end{tabular}

Table 12. Chloride non-steady-state migration coefficients (PC 45)

\begin{tabular}{|c|c|c|c|c|c|c|c|c|c|}
\hline \multirow[b]{2}{*}{ Mix } & \multicolumn{3}{|c|}{$28 d$} & \multicolumn{3}{|c|}{$91 \mathrm{~d}$} & \multicolumn{3}{|c|}{$182 \mathrm{~d}$} \\
\hline & $\begin{array}{l}\text { Chloride } \\
\text { migration } \\
\text { coefficient: } \\
\times 10^{-12} \mathrm{~m}^{2} / \mathrm{s}\end{array}$ & $\begin{array}{c}\text { SD: } \\
\times 10^{-12} \mathrm{~m}^{2} / \mathrm{s}\end{array}$ & $\begin{array}{c}\Delta_{100 \% \mathrm{NA}}: \\
\%\end{array}$ & $\begin{array}{l}\text { Chloride } \\
\text { migration } \\
\text { coefficient: } \\
\times 10^{-12} \mathrm{~m}^{2} / \mathrm{s}\end{array}$ & $\begin{array}{c}\text { SD: } \\
\times 10^{-12} \mathrm{~m}^{2} / \mathrm{s}\end{array}$ & $\begin{array}{c}\Delta_{100 \% \mathrm{NA}}: \\
\%\end{array}$ & $\begin{array}{l}\text { Chloride } \\
\text { migration } \\
\text { coefficient: } \\
\times 10^{-12} \mathrm{~m}^{2} / \mathrm{s}\end{array}$ & $\begin{array}{c}\text { SD: } \\
\times 10^{-12} \mathrm{~m}^{2} / \mathrm{s}\end{array}$ & $\begin{array}{c}\Delta_{100 \% \mathrm{NA}}: \\
\%\end{array}$ \\
\hline $100 \%$ NA & $11 \cdot 3$ & 0.15 & $0 \cdot 0$ & $6 \cdot 1$ & 0.55 & $0 \cdot 0$ & $3 \cdot 7$ & 0.09 & 0.0 \\
\hline $25 \%$ RA & $13 \cdot 2$ & 0.32 & $16 \cdot 8$ & $7 \cdot 0$ & 0.46 & $13 \cdot 9$ & $4 \cdot 7$ & 0.28 & $27 \cdot 8$ \\
\hline $50 \%$ RA & $14 \cdot 7$ & 0.93 & $30 \cdot 5$ & $7 \cdot 5$ & 0.21 & $22 \cdot 8$ & $5 \cdot 8$ & 0.37 & $57 \cdot 1$ \\
\hline $100 \%$ CRA & 11.9 & $1 \cdot 37$ & $5 \cdot 7$ & $6 \cdot 6$ & $1 \cdot 41$ & $6 \cdot 9$ & $4 \cdot 0$ & 0.29 & $6 \cdot 7$ \\
\hline $100 \%$ FRA & $16 \cdot 1$ & 0.46 & $42 \cdot 4$ & $8 \cdot 7$ & 0.96 & $41 \cdot 7$ & $5 \cdot 8$ & 0.52 & $57 \cdot 1$ \\
\hline
\end{tabular}




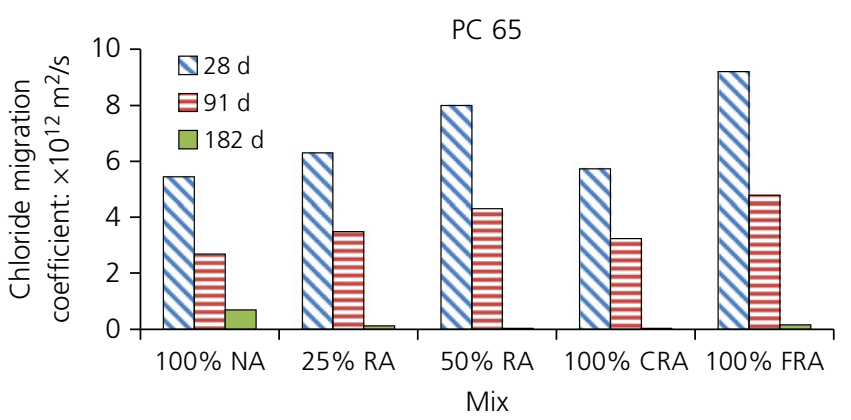

Figure 14. 28, 91 and $182 \mathrm{~d}$ chloride migration coefficient (PC 65)

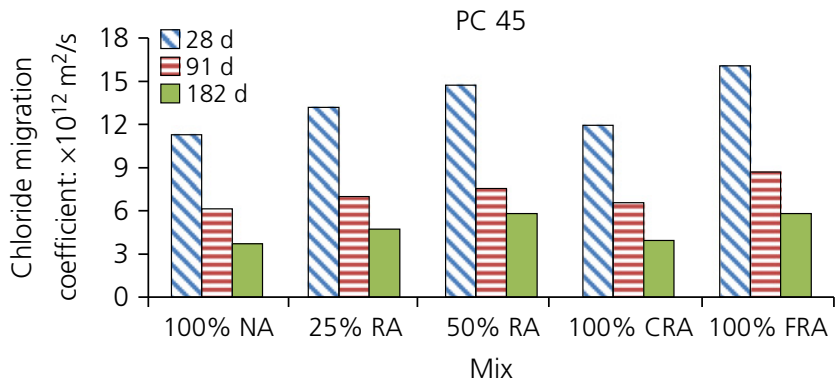

Figure 15. 28, 91 and $182 \mathrm{~d}$ chloride migration coefficient (PC 45)

PC 45 families, respectively. The high correlation coefficients $\left(R^{2}=0.86\right.$ and $R^{2}=0.87$ ) show that these two properties are strongly correlated, and were found to be inversely proportional. Electrical resistivity measures the ability of an element to withstand the passage of current; in other words, this test measures the migration of all ions. On the other hand, the chloride migration coefficient evaluates the ability of an element to be crossed only by chloride ions.

\section{Carbonation test}

Tables 15 and 16 and Figures 22 and 23 show the carbonation test results for both SCC families. For the PC 65 family (Figure 22), carbonation at early ages ( 7 and $28 \mathrm{~d}$ ) was practically non-existent (values up to $1 \mathrm{~mm}$ ) in all the mixes. At $91 \mathrm{~d}$, the maximum carbonation depth of the 100\% FRA mix was less than $3 \mathrm{~mm}$ and did not exceed $9 \mathrm{~mm}$ at $182 \mathrm{~d}$. These low carbonation depths can be explained by the reduced w/c ratio $(0 \cdot 43)$. After $90 \mathrm{~d}$ of exposure to carbon dioxide, Siddique (2011) reported carbonation depths of less than $2 \mathrm{~mm}$ in SCC mixes (without RA) with a w/c ratio of 0.44 . In the PC 45 family (Figure 23), the higher carbonation depths are due to the higher w/c ratio (0.69).

In general, it is possible to state that the carbonation depth tended to increase with an increase of the substitution ratio of NA with RA, especially with the presence of FRA in the mix.

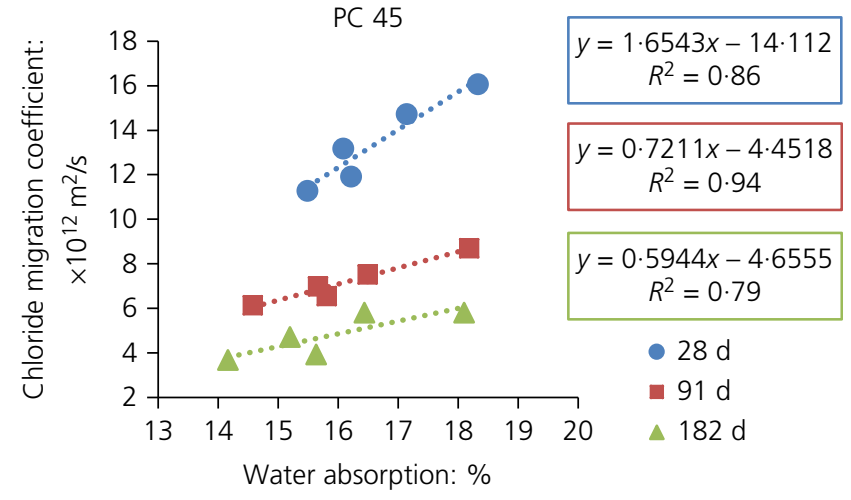

Figure 16. Chloride migration coefficient plotted against water absorption for PC 45

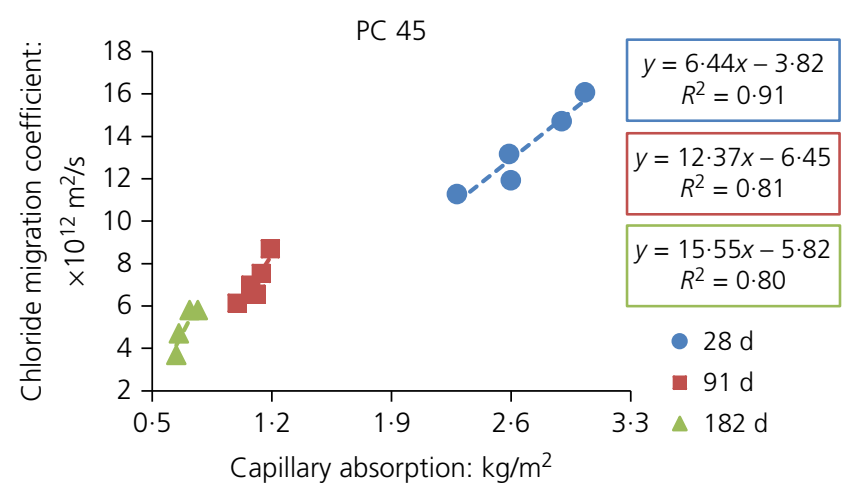

Figure 17. Chloride migration coefficient plotted against capillary absorption for PC 45

The mixes with 100\% CRA showed smaller carbonation depths than those of the 25\% RA mixes (substitution with FRA and CRA). It can thus be concluded that a mortar phase change is more relevant for the propagation of carbonation inside concrete than alteration of the coarse aggregate phase. This was expected, as the water absorption and capillary absorption results presented identical trends.

For SCC with $100 \%$ FRA, the carbonation depth increased by $560 \%$ (PC 65) and 55\% (PC 45) at $91 \mathrm{~d}$ compared with the reference mixes. This greater depth of carbonation in SCC with FRA is related to its greater porosity, as verified by the increases in total volume and average diameter of the pores with the incorporation of FRA (Kou and Poon, 2009).

Tables 17 and 18 list the values of the carbonation coefficients. As expected, the greatest variation compared with the reference SCC was found in the $100 \%$ FRA mixes $(667 \%$ for the PC 65 family and $56 \%$ for the PC 45 family). Linear relationships were found between the carbonation coefficient and water absorption (Figure 24) and between the carbonation coefficient and capillary absorption (Figure 25). 
Table 13. Electrical resistivity at 28, 91 and $182 \mathrm{~d}$ (PC 65)

\begin{tabular}{|c|c|c|c|c|c|c|c|c|c|}
\hline \multirow[b]{2}{*}{ Mix } & \multicolumn{3}{|c|}{$28 d$} & \multicolumn{3}{|c|}{$91 \mathrm{~d}$} & \multicolumn{3}{|c|}{$182 \mathrm{~d}$} \\
\hline & $\begin{array}{c}\text { Electrical } \\
\text { resistivity: } \Omega . \mathrm{m}\end{array}$ & SD: $\Omega . \mathrm{m}$ & $\Delta_{100 \% \text { NA }}: \%$ & $\begin{array}{c}\text { Electrical } \\
\text { resistivity: } \Omega . \mathrm{m}\end{array}$ & SD: $\Omega . m$ & $\Delta_{100 \% \mathrm{NA}}: \%$ & $\begin{array}{c}\text { Electrical } \\
\text { resistivity: } \Omega . \mathrm{m}\end{array}$ & SD: $\Omega . m$ & $\Delta_{100 \% \text { NA }}: \%$ \\
\hline $100 \%$ NA & $220 \cdot 4$ & $3 \cdot 6$ & $0 \cdot 0$ & $661 \cdot 0$ & $15 \cdot 9$ & 0.0 & $796 \cdot 9$ & $10 \cdot 6$ & 0.0 \\
\hline $25 \%$ RA & $203 \cdot 1$ & $18 \cdot 2$ & $-7 \cdot 9$ & $374 \cdot 3$ & $28 \cdot 3$ & $-43 \cdot 4$ & $400 \cdot 3$ & 0.4 & $-49 \cdot 8$ \\
\hline $50 \%$ RA & $136 \cdot 3$ & $3 \cdot 4$ & $-38 \cdot 2$ & $252 \cdot 0$ & $1 \cdot 2$ & $-61 \cdot 9$ & $295 \cdot 1$ & $15 \cdot 2$ & $-63 \cdot 0$ \\
\hline $100 \%$ CRA & $178 \cdot 3$ & $0 \cdot 3$ & $-19 \cdot 1$ & $295 \cdot 9$ & $9 \cdot 2$ & $-55 \cdot 2$ & $390 \cdot 1$ & $18 \cdot 3$ & $-51 \cdot 1$ \\
\hline $100 \%$ FRA & $119 \cdot 3$ & 0.2 & -45.9 & $243 \cdot 1$ & $11 \cdot 2$ & $-63 \cdot 2$ & $253 \cdot 1$ & $16 \cdot 1$ & $-68 \cdot 2$ \\
\hline
\end{tabular}

Table 14. Electrical resistivity at 28, 91 and $182 \mathrm{~d}$ (PC 45)

\begin{tabular}{|c|c|c|c|c|c|c|c|c|c|}
\hline \multirow[b]{2}{*}{ Mix } & \multicolumn{3}{|c|}{$28 d$} & \multicolumn{3}{|c|}{$91 \mathrm{~d}$} & \multicolumn{3}{|c|}{$182 d$} \\
\hline & $\begin{array}{c}\text { Electrical } \\
\text { resistivity: } \Omega . \mathrm{m}\end{array}$ & SD: $\Omega . \mathrm{m}$ & $\Delta_{100 \% \mathrm{NA}} \%$ & $\begin{array}{l}\text { Electrical } \\
\text { resistivity: } \Omega . \mathrm{m}\end{array}$ & SD: $\Omega . \mathrm{m}$ & $\Delta_{100 \% \text { NA }} \%$ & $\begin{array}{c}\text { Electrical } \\
\text { resistivity: } \Omega . \mathrm{m}\end{array}$ & SD: $\Omega . \mathrm{m}$ & $\Delta_{100 \% \text { NA }} \%$ \\
\hline $100 \%$ NA & $218 \cdot 2$ & $50 \cdot 6$ & 0.0 & $467 \cdot 1$ & $26 \cdot 6$ & 0.0 & $522 \cdot 5$ & $28 \cdot 0$ & 0.0 \\
\hline $25 \%$ RA & $169 \cdot 9$ & $1 \cdot 6$ & $-22 \cdot 2$ & $364 \cdot 0$ & $10 \cdot 8$ & $-22 \cdot 1$ & $400 \cdot 1$ & $37 \cdot 8$ & $-23 \cdot 4$ \\
\hline $50 \%$ RA & $110 \cdot 2$ & $6 \cdot 1$ & $-49 \cdot 5$ & $274 \cdot 7$ & $22 \cdot 6$ & $-41 \cdot 2$ & $368 \cdot 1$ & $19 \cdot 2$ & $-29 \cdot 6$ \\
\hline $100 \%$ CRA & $152 \cdot 7$ & $1 \cdot 5$ & $-30 \cdot 0$ & $292 \cdot 3$ & $10 \cdot 8$ & $-37 \cdot 4$ & $385 \cdot 2$ & $16 \cdot 6$ & $-26 \cdot 3$ \\
\hline $100 \%$ FRA & $75 \cdot 2$ & $56 \cdot 1$ & $-65 \cdot 5$ & $247 \cdot 0$ & $3 \cdot 4$ & $-47 \cdot 1$ & $326 \cdot 3$ & $19 \cdot 0$ & $-37 \cdot 6$ \\
\hline
\end{tabular}

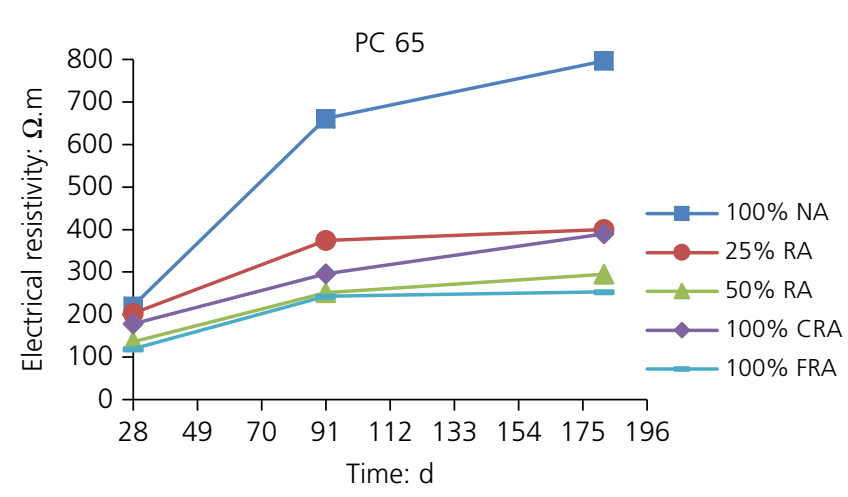

Figure 18. 28, 91 and 182 d electrical resistivity (PC 65)

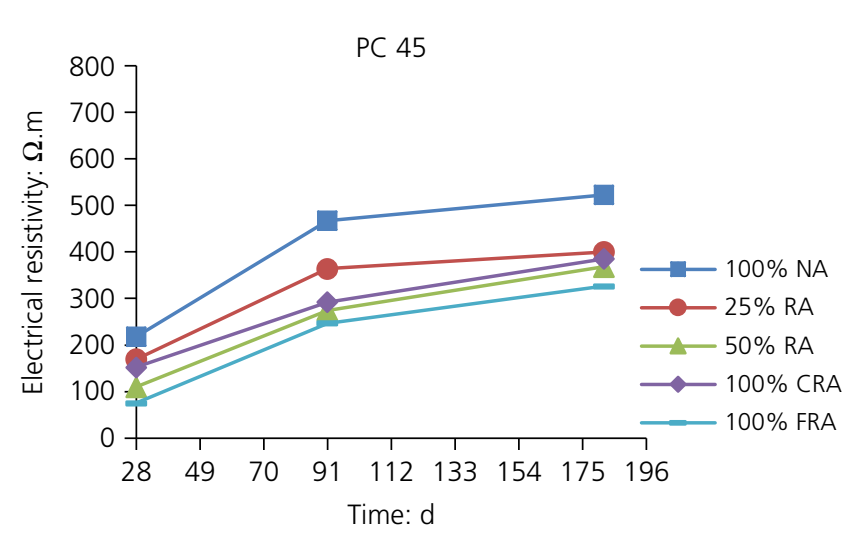

Figure 19. 28, 91 and 182 d electrical resistivity (PC 45)

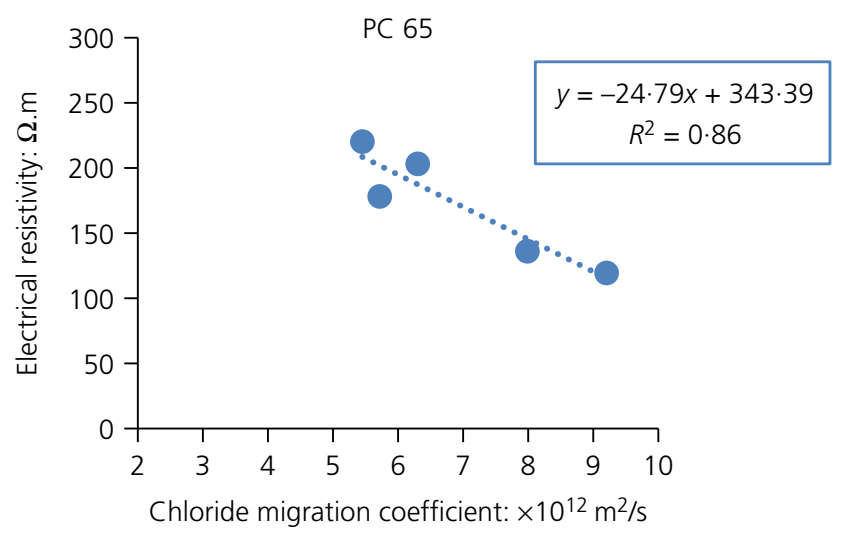

Figure 20. Electrical resistivity at $28 \mathrm{~d}$ plotted against chloride migration coefficient for PC 65

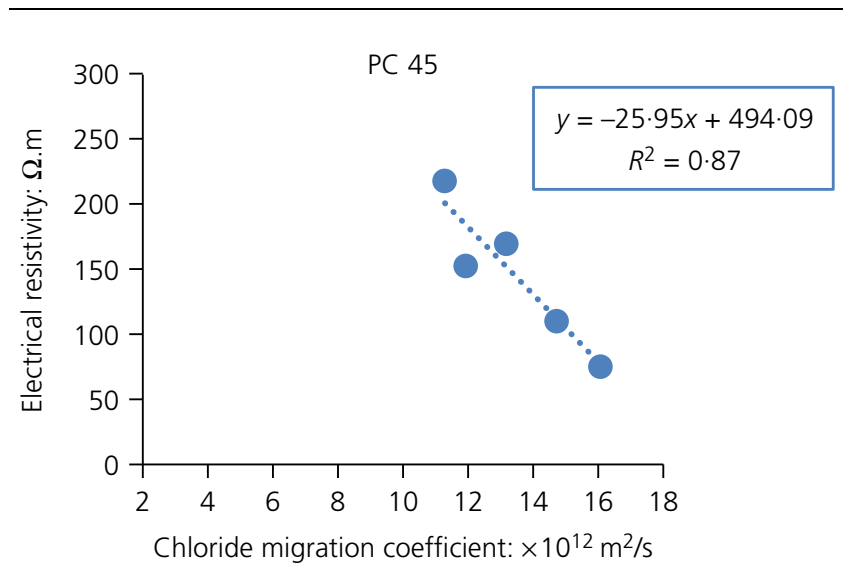

Figure 21. Electrical resistivity at $28 \mathrm{~d}$ plotted against chloride migration coefficient for PC 45 
Table 15. Carbonation test results at 7, 56, 28, 91 and $182 \mathrm{~d}$ (PC 65)

\begin{tabular}{|c|c|c|c|c|c|c|c|c|c|c|c|c|c|c|c|}
\hline \multirow[b]{2}{*}{ Mix } & \multicolumn{3}{|c|}{$7 d$} & \multicolumn{3}{|c|}{$28 \mathrm{~d}$} & \multicolumn{3}{|c|}{$56 \mathrm{~d}$} & \multicolumn{3}{|c|}{$91 \mathrm{~d}$} & \multicolumn{3}{|c|}{$182 \mathrm{~d}$} \\
\hline & $\begin{array}{l}\text { Carbonation } \\
\text { depth: } \mathrm{mm}\end{array}$ & $\begin{array}{l}\text { SD: } \\
\mathrm{mm}\end{array}$ & $\begin{array}{c}\Delta_{100 \% \text { NA }}: \\
\%\end{array}$ & $\begin{array}{l}\text { Carbonation } \\
\text { depth: } \mathrm{mm}\end{array}$ & $\begin{array}{l}\text { SD: } \\
\mathrm{mm}\end{array}$ & $\begin{array}{c}\Delta_{100 \% \text { NA }}: \\
\%\end{array}$ & $\begin{array}{l}\text { Carbonation } \\
\text { depth: } \mathrm{mm}\end{array}$ & $\begin{array}{l}\text { SD: } \\
\mathrm{mm}\end{array}$ & $\begin{array}{c}\Delta_{100 \% \text { NA }}: \\
\%\end{array}$ & $\begin{array}{l}\text { Carbonation } \\
\text { depth: } \mathrm{mm}\end{array}$ & $\begin{array}{l}\text { SD: } \\
\mathrm{mm}\end{array}$ & $\begin{array}{c}\Delta_{100 \% \text { NA }}: \\
\%\end{array}$ & $\begin{array}{l}\text { Carbonation } \\
\text { depth: } \mathrm{mm}\end{array}$ & $\begin{array}{l}\text { SD: } \\
\mathrm{mm}\end{array}$ & $\begin{array}{c}\Delta_{100 \% \text { NA }}: \\
\%\end{array}$ \\
\hline $100 \%$ NA & 0.0 & 0.0 & 0 & $0 \cdot 2$ & 0.0 & 0 & $0 \cdot 3$ & - & 0 & 0.4 & - & 0 & $1 \cdot 1$ & 0.0 & 0.0 \\
\hline $25 \%$ RA & $0 \cdot 0$ & $0 \cdot 0$ & 0 & 0.7 & $0 \cdot 1$ & 294 & $0 \cdot 9$ & - & 164 & $2 \cdot 3$ & - & 413 & $5 \cdot 0$ & 0.5 & 347 \\
\hline $50 \%$ RA & 0.0 & 0.0 & 0 & 0.8 & 0.2 & 297 & $2 \cdot 6$ & - & 673 & $2 \cdot 8$ & - & 518 & $6 \cdot 1$ & 0.3 & 444 \\
\hline $100 \%$ CRA & 0.0 & 0.0 & 0 & $0 \cdot 6$ & $0 \cdot 1$ & 198 & $0 \cdot 7$ & - & 93 & $0 \cdot 8$ & - & 79 & $1 \cdot 1$ & 0.4 & 3 \\
\hline $100 \%$ FRA & $1 \cdot 2$ & $0 \cdot 3$ & 0 & $1 \cdot 2$ & $0 \cdot 3$ & 539 & $2 \cdot 9$ & - & 755 & $2 \cdot 9$ & - & 560 & $8 \cdot 6$ & 1.0 & 670 \\
\hline
\end{tabular}

Table 16. Carbonation test results at 7, 56, 28, 91 and $182 \mathrm{~d}$ (PC 45)

\begin{tabular}{|c|c|c|c|c|c|c|c|c|c|c|c|c|c|c|c|}
\hline \multirow[b]{2}{*}{ Mix } & \multicolumn{3}{|c|}{$7 d$} & \multicolumn{3}{|c|}{$28 \mathrm{~d}$} & \multicolumn{3}{|c|}{$56 \mathrm{~d}$} & \multicolumn{3}{|c|}{$91 \mathrm{~d}$} & \multicolumn{3}{|c|}{$182 \mathrm{~d}$} \\
\hline & $\begin{array}{l}\text { Carbonation } \\
\text { depth: } \mathrm{mm}\end{array}$ & $\begin{array}{l}\text { SD: } \\
\mathrm{mm}\end{array}$ & $\begin{array}{c}\Delta_{100 \% \text { NA }}: \\
\%\end{array}$ & $\begin{array}{l}\text { Carbonation } \\
\text { depth: } \mathrm{mm}\end{array}$ & $\begin{array}{l}\text { SD: } \\
\mathrm{mm}\end{array}$ & $\begin{array}{c}\Delta_{100 \% \text { NA }}: \\
\%\end{array}$ & $\begin{array}{l}\text { Carbonation } \\
\text { depth: } \mathrm{mm}\end{array}$ & $\begin{array}{l}\text { SD: } \\
\mathrm{mm}\end{array}$ & $\begin{array}{c}\Delta_{100 \% \text { NA: }}: \\
\%\end{array}$ & $\begin{array}{l}\text { Carbonation } \\
\text { depth: } \mathrm{mm}\end{array}$ & $\begin{array}{l}\text { SD: } \\
\mathrm{mm}\end{array}$ & $\begin{array}{c}\Delta_{100 \% \text { NA: }}: \\
\%\end{array}$ & $\begin{array}{l}\text { Carbonation } \\
\text { depth: } \mathrm{mm}\end{array}$ & $\begin{array}{l}\mathrm{SD}: \\
\mathrm{mm}\end{array}$ & $\begin{array}{c}\Delta_{100 \% \text { NA: }}: \\
\%\end{array}$ \\
\hline $100 \%$ NA & $3 \cdot 6$ & $0 \cdot 1$ & 0 & $9 \cdot 4$ & 0.5 & 0 & 11.8 & - & 0 & $15 \cdot 1$ & - & 0 & $23 \cdot 2$ & 0.6 & 0 \\
\hline $25 \%$ RA & $5 \cdot 3$ & $0 \cdot 2$ & 50 & $12 \cdot 6$ & $0 \cdot 8$ & 34 & $14 \cdot 2$ & - & 21 & $20 \cdot 8$ & - & 38 & $30 \cdot 7$ & $0 \cdot 1$ & 32 \\
\hline $50 \%$ RA & $5 \cdot 8$ & 0.4 & 63 & $13 \cdot 5$ & $0 \cdot 8$ & 44 & $17 \cdot 4$ & - & 48 & $22 \cdot 7$ & - & 50 & $31 \cdot 3$ & 0.5 & 35 \\
\hline $100 \%$ CRA & $5 \cdot 0$ & $1 \cdot 3$ & 40 & $11 \cdot 8$ & 0.6 & 25 & $12 \cdot 5$ & - & 7 & $20 \cdot 6$ & - & 36 & $25 \cdot 4$ & 0.5 & 10 \\
\hline $100 \%$ FRA & $6 \cdot 1$ & $0 \cdot 1$ & 70 & $14 \cdot 0$ & 0.4 & 49 & $18 \cdot 8$ & - & 60 & $23 \cdot 4$ & - & 55 & $36 \cdot 4$ & 0.5 & 57 \\
\hline
\end{tabular}




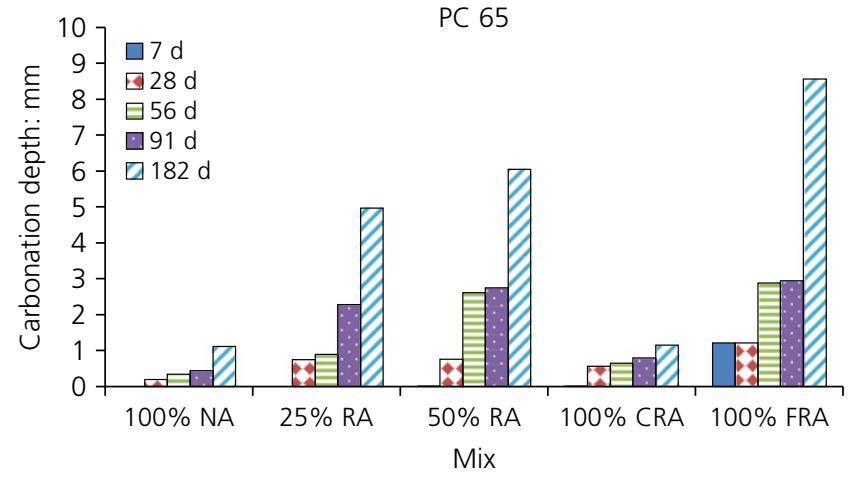

Figure 22. 7, 56, 28, 91 and 182 d carbonation depth (PC 65)

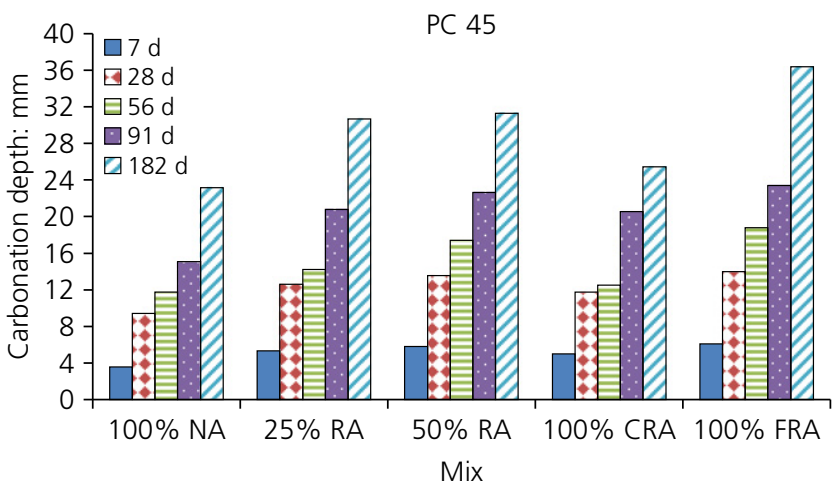

Figure 23. 7, 56, 28, 91 and $182 \mathrm{~d}$ carbonation depth (PC 45)

Table 17. Carbonation coefficients (PC 65)

\begin{tabular}{|lccc|}
\hline Mix & $\begin{array}{c}\text { Carbonation } \\
\text { coefficient: } \mathbf{~ m m} / \mathbf{d}^{\mathbf{0 . 5}}\end{array}$ & $\boldsymbol{R}^{\mathbf{2}}$ & $\boldsymbol{\Delta}_{\mathbf{1 0 0 \% N A}:}$ \% \\
\hline $100 \%$ NA & 0.063 & 0.78 & 0 \\
$25 \%$ RA & 0.273 & 0.73 & 337 \\
$50 \%$ RA & 0.361 & 0.81 & 477 \\
$100 \%$ CRA & 0.085 & 0.91 & 36 \\
$100 \%$ FRA & 0.480 & 0.75 & 667 \\
\hline
\end{tabular}

Table 18. Carbonation coefficients (PC 45)

\begin{tabular}{lccc} 
Mix & $\begin{array}{c}\text { Carbonation } \\
\text { coefficient: } \mathbf{~ m m} / \mathbf{d}^{\mathbf{0 . 5}}\end{array}$ & $\boldsymbol{R}^{\mathbf{2}}$ & $\boldsymbol{\Delta}_{\mathbf{1 0 0 \%} \mathbf{N A}: \%}$ \\
\hline $100 \%$ NA & 1.659 & 0.99 & 0 \\
$25 \%$ RA & 2.196 & 0.98 & 32 \\
$50 \%$ RA & 2.351 & 0.99 & 42 \\
$100 \%$ CRA & 1.946 & 0.96 & 17 \\
$100 \%$ FRA & 2.595 & 0.99 & 56 \\
\hline
\end{tabular}

\section{Global analysis of results}

A global analysis of the results revealed that the different mixes with incorporation of RA presented coherent variations.

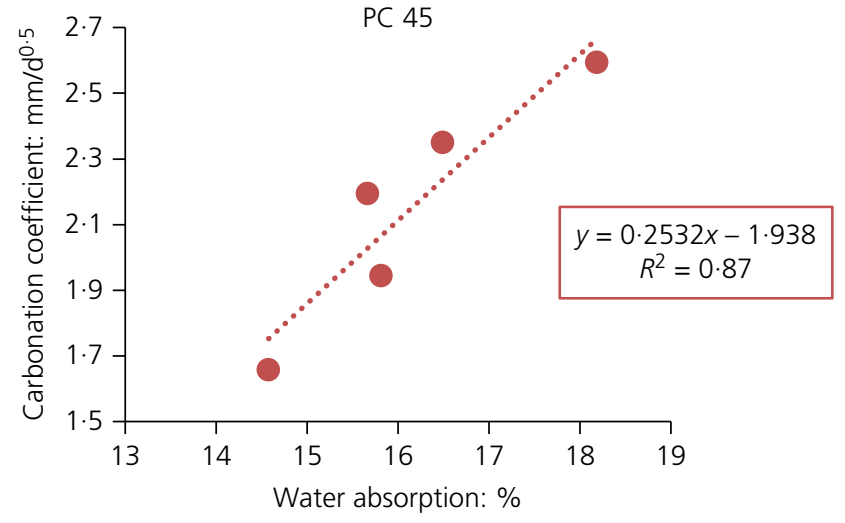

Figure 24. Carbonation coefficient at $91 \mathrm{~d}$ plotted against water absorption for PC 45

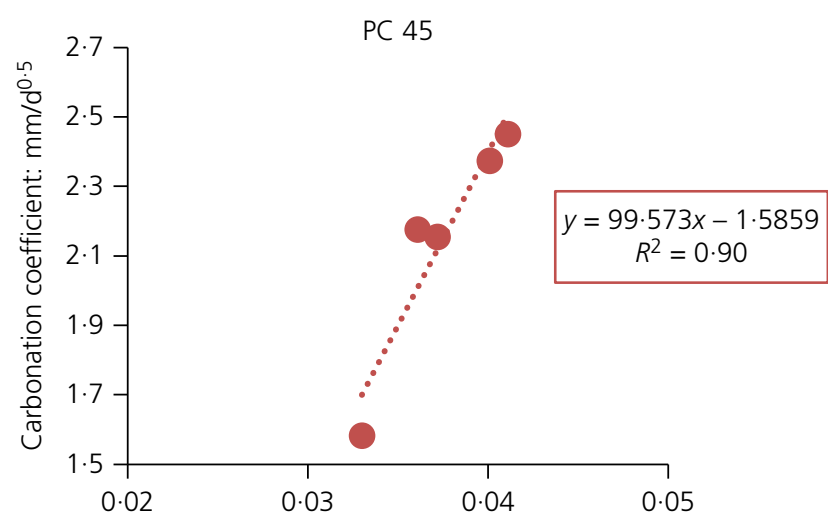

Capillary water absorption coefficient: $\mathrm{kg} /\left(\mathrm{m}^{2} \cdot \mathrm{min}^{0 \cdot 5}\right)$

Figure 25. Carbonation coefficient at $91 \mathrm{~d}$ plotted against capillary water absorption coefficient for PC 45

Mixes with $25 \%$ RA showed the best performance in both families, with losses of less than $22 \%$ in terms of durability (except for oxygen penetration and carbonation resistance).

CRA have much less influence on the durability performance of SCC than FRA, because this parameter is mainly controlled by the mortar phase, where the transport and degradation mechanisms of concrete preferentially occur. Weakening the mortar phase (with the incorporation of FRA) favours the penetration of degradation agents (water, oxygen, carbon dioxide and chlorides).

There was a performance decrease in terms of oxygen permeability, water absorption and capillarity due to the incorporation of FRA. The presence of old adhered mortar in RA is responsible for greater concrete porosity. For these three properties, there was a decrease in the penetration of the oxygen and water with age, which can be explained by the decrease in capillary pore size. The presence of FRA causes an increase in 
the mean pore size at younger ages but the pore volume tends to decrease for more advanced ages, thus decreasing the penetration rate. It was also observed that, for these three properties, the SCCs with $100 \%$ CRA performed better than the SCCs with 50\% RA, due to CRA having water absorption values well below those of FRA. The mortar phase remains unchanged (only with NA), which leads to an improvement compared with SCC with 50\% RA.

An increase in the substitution ratio of NA with RA was found to increase the penetration of chloride ions (increases of 5-69\% for the PC 65 family and $6-42 \%$ for the PC 45 family, at $28 \mathrm{~d}$ ). This can be explained by the degradation of the quality of the mortar phase in the SCC (due to the substitution of natural sand with FRA), since ion transport takes place preferentially in that medium. This also explains why the $100 \%$ CRA mixes showed the best performance of the SCCs with RA, since there was no substitution of NA with RA at the mortar phase level.

Analysing the transport mechanisms of all types of ions in the SCCs (through electrical resistivity tests), it was found that electrical resistivity increased with the substitution of NA with $\mathrm{RA}$, which is in accordance with the chloride ion penetration test. The PC 65 and PC 45 families showed increases of $8-46 \%$ and $22-66 \%$, respectively, at $28 \mathrm{~d}$.

At an early age, the carbonation depth in the PF 65 family was imperceptible and only began to be visible after $56 \mathrm{~d}$. At $91 \mathrm{~d}$, the maximum carbonation depth, corresponding to the mix with $100 \%$ FRA, was less than $3 \mathrm{~mm}$ (very low). This can be explained by the reduced w/c ratio used in these mixes $(w / c=0 \cdot 43)$. The carbonation depths tended to increase with an increase of the substitution ratio of NA with RA at the FRA level. The mixes with $100 \%$ CRA presented carbonation depths less than those of the $25 \%$ RA mixes, so it is concluded that a mortar phase change is more relevant for carbonation propagation in concrete than a change to the coarse aggregate phase. This situation was expected, as the water absorption and capillarity presented similar trends.

\section{Concluding remarks}

For better visualisation of the durability results obtained, summaries are provided in Tables 19 and 20 for the PC 65 and PC 45 families, respectively: a negative sign corresponds to a decrease and a positive sign corresponds to an increase in the value of the property under analysis in relation to the reference concrete $(100 \% \mathrm{NA})$.

A performance decrease in terms of water absorption and capillarity was found due to the incorporation of FRA, because of the greater porosity caused by the old mortar adhered to the RA. The SCCs with $100 \%$ CRA showed better performance than those with $50 \%$ RA, because CRA has much lower water absorption values than FRA.
Table 19. Hardened state $28 \mathrm{~d}$ test results of the SCC mixes (PF 65)

\begin{tabular}{lcccc} 
& \multicolumn{4}{c}{$\begin{array}{c}\text { Respective increase/decrease } \\
\text { relative to reference SCC: } \%\end{array}$} \\
\cline { 2 - 5 } & $25 \%$ & $50 \%$ & $100 \%$ & $100 \%$ \\
Durability property & RA & RA & CRA & FRA \\
\hline Water absorption & $21^{\mathrm{a}}$ & 36 & 25 & $41^{\mathrm{b}}$ \\
Capillary absorption & $11^{\mathrm{a}}$ & 33 & 28 & $41^{\mathrm{b}}$ \\
Oxygen permeability & $42^{\mathrm{a}}$ & 433 & 99 & $669^{\mathrm{b}}$ \\
Chloride migration test & 16 & 47 & $5^{\mathrm{a}}$ & $69^{\mathrm{b}}$ \\
Electrical resistivity & $-8^{\mathrm{a}}$ & -38 & -19 & $-46^{\mathrm{b}}$ \\
Carbonation test (91 d) & 413 & 518 & $79^{\mathrm{a}}$ & $560^{\mathrm{b}}$ \\
\end{tabular}

${ }^{\mathrm{a}}$ Better result

borse result

Table 20. Hardened state $28 d$ test results of the SCC mixes (PF 45)

\begin{tabular}{lcccc} 
& \multicolumn{4}{c}{$\begin{array}{c}\text { Respective increase/decrease } \\
\text { relative to reference SCC: \% }\end{array}$} \\
\cline { 2 - 5 } & $25 \%$ & $50 \%$ & $100 \%$ & $100 \%$ \\
Durability properties & RA & RA & CRA & FRA \\
\hline Water absorption & $5^{\mathrm{a}}$ & 11 & 5 & $18^{\mathrm{b}}$ \\
Capillary absorption & $13^{\mathrm{a}}$ & 27 & 25 & $33^{\mathrm{b}}$ \\
Oxygen permeability & $41^{\mathrm{a}}$ & 240 & 178 & $518^{\mathrm{b}}$ \\
Chloride migration test & 17 & 31 & $6^{\mathrm{a}}$ & $42^{\mathrm{b}}$ \\
Electrical resistivity & $-22^{\mathrm{a}}$ & -50 & -30 & $-66^{\mathrm{b}}$ \\
Carbonation test (91 d) & 38 & 50 & $36^{\mathrm{a}}$ & $55^{\mathrm{b}}$ \\
& & & &
\end{tabular}

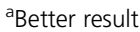

borse result

The oxygen permeability increased with the substitution of NA with RA for the same reason. The variations relative to the reference SCCs were quite high. However, at $91 \mathrm{~d}$, for the PF 65 family, all the SCCs presented good resistance to oxygen penetration according to the classification proposed in Rilem TC 116-PCD (Rilem, 1999). In the PC 45 family, only the SCC with $100 \%$ NA presented moderate resistance, while the rest showed low resistance.

The electrical resistivity and chloride diffusion coefficient were found to be strongly correlated. It was found that an increase in the substitution ratio of NA with RA increased the penetration of chloride ions, which can be explained by the degradation of the quality of the mortar phase (mainly due to the replacement of sand with FRA), since ion transport occurs preferentially in that zone. This explains why the $100 \%$ CRA mixes showed the best performance of the SCCs with RA, since there was no substitution of NA for RA at the mortar phase level. Conversely, the electrical resistivity was found to decrease with the ratio of substitution of NA with RA, which is explained by the higher porosity of RA compared with NA, mainly due to old adhered mortar. 
The carbonation depth was found to increase with the replacement of FNA with FRA, and hence it is concluded that a change in the mortar phase influences this property. Despite the large variations in relation to the reference SCC, it was found that the carbonation depth at $91 \mathrm{~d}$ was less than $3 \mathrm{~mm}$ and $24 \mathrm{~mm}$ for the PC 65 and PC 45 families, respectively.

Finally, based on the results of the experimental work carried out, the following general conclusions are presented.

- The aggregates used, coming from rejects from the precast industry, were of excellent quality, with performance superior to that reported in a large proportion of other investigations consulted.

- In terms of the durability properties, SCCs made with 50\% RA and 100\% FRA showed considerable losses. However, incorporation ratios of 25\% RA (FRA and CRA) and $100 \%$ CRA are feasible.

- Broadly speaking, and taking into account all the properties studied, RA from precast concrete elements can be used in SCC production, at the ratio limits just stated.

- In conclusion, it is considered that an increase in the limits of the incorporation ratios of these types of aggregates stated in existing regulations is feasible, provided that their quality is proven (as is the case for aggregates from precast concrete elements).

\section{Acknowledgements}

The authors acknowledge the support of the Foundation for Science and Technology through funding received regarding project reference SFRH/PROTEC/67426/2010. The support of the CERIS-ICIST Research Institute, Instituto Superior Técnico of the University of Lisbon, is also acknowledged.

\section{REFERENCES}

Bogas J, Gomes A and Pereira M (2012) Self-compacting lightweight concrete produced with expanded clay aggregate. Construction and Building Materials 35: 1013-1022, https://doi.org/10.1016/ j.conbuildmat.2012.04.111.

Boudali S, Kerdal D, Ayed K and Abdulsalam B (2016) Performance of self-compacting concrete incorporating recycled concrete fines and aggregate exposed to sulphate attack. Construction and Building Materials 124: 705-713, https://doi.org/10.1016/j.conbuildmat. 2016.06.058.

Camões A (2002) Betões de Elevado Desempenho com Incorporação de Cinzas Volantes. PhD thesis, University of Minho, Guimarães, Portugal (in Portuguese).

DURAR (2000) Thematic Network XV.B Durability of Rebars, Manual for Inspecting, Evaluating and Diagnosing Corrosion in Reinforced Concrete Structures. CYTED, Ibero-American Program Science and Technology for Development, Subprogram XV, Corrosion/Environmental Impact on Materials, Maracaibo, Venezuela.

Fischer C and Werge M (2009) EU as a Recycling Society: Present Recycling Levels of Municipal Waste and Construction \&
Demolition Waste in the EU. ETC/SCP Working Paper. European Environment Agency, Copenhagen, Denmark. Gómez-Soberón J (2002) Porosity of recycled concrete with substitution of recycled concrete aggregate: an experimental study. Cement and Concrete Research 32(8): 1301-1311.

Gonçalves P (2007) Concrete with Recycled Aggregates: Commented Analysis of Existing Legislation. Master's thesis, Instituto Superior Técnico, Universidade Técnica de Lisboa, Lisbon, Portugal.

Grdic Z, Toplicic-Curcic G, Despotovic I and Ristic N (2010) Properties of self-compacting concrete prepared with coarse recycled concrete aggregate. Construction and Building Materials 24(7): 1129-1133.

Güneyisi E, Gesoglu M, Algın Z and Yazıcı H (2016) Rheological and fresh properties of self-compacting concretes containing coarse and fine recycled concrete aggregates. Construction and Building Materials 113: 622-630, https://doi.org/10.1016/j.conbuildmat. 2016.03.073.

Hansen T and Boegh E (1985) Elasticity and drying shrinkage of recycled aggregate concrete. ACI Journal 82(5): 648-652.

IPQ (Instituto Português da Qualidade) (2003) NP EN 1008: Água de amassadura para betão. Especificações para a amostragem, ensaio e avaliação da aptidão da água, incluindo água recuperada nos processos da industria de betão, para o fabrico de betão. IPQ, Lisbon, Portugal (in Portuguese).

IPQ (2006) NP EN 450-2: Cinzas volantes para betão. Parte 2: Avaliação da conformidade. IPQ, Lisbon, Portugal (in Portuguese).

IPQ (2008a) NP EN 197-1: Cimento. Parte 1: Composição, especificações e critérios de conformidade para cimentos correntes. IPQ, Lisbon, Portugal (in Portuguese).

IPQ (2008b) NP EN 450-1: Cinzas volantes para betão. Parte 1: Definição, especificações e critérios de conformidade. IPQ, Lisbon, Portugal (in Portuguese).

IPQ (2008c) NP EN 934-1: Adjuvantes para betão, argamassa e caldas de injecção. Parte 1: Requisitos gerais. IPQ, Lisbon, Portugal (in Portuguese).

IPQ (2009) NP EN 934-2: Adjuvantes para betão, argamassa e caldas de injecção. Parte 2: Adjuvantes para betão. Definições, requisitos, conformidade, marcação e etiquetagem. IPQ, Lisbon, Portugal (in Portuguese).

IPQ (2010a) NP EN 12620: Agregados para betão. IPQ, Lisbon, Portugal (in Portuguese).

IPQ (2010b) NP EN 206-9: Betão - Parte 9: Regras adicionais para BAC. IPQ, Lisbon, Portugal (in Portuguese).

Kapoor K, Singh S and Singh B (2016) Durability of self-compacting concrete made with recycled concrete aggregates and mineral admixtures. Construction and Building Materials 128: 67-76.

Kou S and Poon C (2009) Properties of self-compacting concrete prepared with coarse and fine recycled concrete aggregates. Cement \& Concrete Composites 31: 622-627.

LNEC (National Laboratory of Civil Engineering) (1993a) E394: Betões. Absorção de água por imersão, ensaio à pressão atmosférica. LNEC, Lisbon, Portugal (in Portuguese).

LNEC (1993b) E393: Betões. Determinação da absorção de água por capilaridade. LNEC, Lisbon, Portugal (in Portuguese).

LNEC (1993c) E392: Betões. Determinação da permeabilidade ao oxigênio. LNEC, Lisbon, Portugal (in Portuguese).

LNEC (1993d) E391: Betões. Determinação da resistência à carbonatação. LNEC, Lisbon, Portugal (in Portuguese).

LNEC (2004) E463: Betões. Determinação do coeficiente de difusão dos cloretos por ensaio de migração em regime não estacionário. LNEC, Lisbon, Portugal (in Portuguese).

LNEC (2005) E466: Fíleres calcários para ligantes hidráulicos. LNEC, Lisbon, Portugal (in Portuguese).

LNEC (2009) E471: Guia para a utilização de agregados reciclados grossos em betões de ligantes hidráulicos. LNEC, Lisbon, Portugal (in Portuguese). 
Luping T (2005) Guidelines for Practical Use of Methods for Testing the Resistance of Concrete to Chloride Ingress. EU-Project Chlortest (EU Funded Research Project under 5FP GROWTH Programme). Swedish National Testing and Research Institute, Boras, Sweden.

Manzi S, Mazzotti C and Bignozzi M (2017) Self-compacting concrete with recycled concrete aggregate: study of the long-term properties Construction and Building Materials 157: 582-590, https://doi.org/ 10.1016/j.conbuildmat.2017.09.129.

Matias D, de Brito J, Rosa A and Pedro D (2013) Mechanical properties of concrete produced with recycled coarse aggregates - influence of the use of superplasticizers. Construction and Building Materials 44: 101-109, https://doi.org/10.1016/j.conbuildmat.2013. 03.011 .

Modani P and Mohitkar V (2014) Self-compacting concrete with recycled aggregate: a solution for sustainable development. International Journal of Civil and Structural Engineering 4(3) $430-440$.

Nagatakia S, Gokceb A, Saekic T and Hisada M (2004) Assessment of recycling process induced damage sensitivity of recycled concrete aggregates. Cement and Concrete Research 34(6): $965-971$.

Nepomuceno M and Oliveira L (2008) Parameters for self-compacting concrete mortar phase. ACI Materials Journal 253: 323-340.

Nepomuceno M, Oliveira L and Lopes S (2012) Methodology for mix design of the mortar phase of self-compacting concrete using different mineral additions in binary blends of powders. Construction and Building Materials 26(1): 317-326.

Nordtest (1999) NT Build 492: Concrete, mortar and cement-based repair materials, chloride migration coefficient from non-steadystate migration experiments. Nordtest, Espoo, Finland.

Pereira-de-Oliveira L, Nepomuceno M, Castro-Gomes J and Vila M (2014) Permeability properties of self-compacting concrete with coarse recycled aggregates. Construction and Building Materials 51: 113-120, https://doi.org/10.1016/j.conbuildmat.2013.10.061.
Polder R (2000) Test methods for on-site measurement of resistivity of concrete. Rilem TC 154-EMC: electrochemical techniques for measuring metallic corrosion. Materials and Structures 15(2-3): $125-131$.

Rilem (Réunion Internationale des Laboratoires et Experts des Matériaux) (1988) CPC-18: measurement of hardened concrete carbonation depth. Materials and Structures 21(6): 453-455.

Rilem (1999) TC 116-PCD: tests for gas permeability of concrete. Materials and Structures 32: 174-179.

Siddique R (2011) Properties of self-compacting concrete containing class F fly ash. Materials \& Design 32(3): 1501-1507.

Silva P and de Brito J (2015) Fresh-state properties of self-compacting mortar and concrete with combined use of limestone filler and fly ash. Materials Research, Ibero-American Journal of Materials 18(5): 1097-1108.

Silva P, de Brito J and Costa J (2011) Viability of two new mixture design methodologies for self-consolidating concrete (SCC). ACI Materials Journal 108(6): 579-588.

Surya M, Kanta Rao VVL and Lakshmy P (2013) Recycled aggregate concrete for transportation infrastructure. Procedia - Social and Behavioral Sciences 104: 1501-1507.

Tuyan M, Mardani-Aghabaglou A and Ramyar K (2014) Freeze-thaw resistance, mechanical and transport properties of self-consolidating concrete incorporating coarse recycled concrete aggregate. Materials \& Design 53: 983-991.

Uygunoğlu T, Topçu I and Çelik A (2014) Use of waste marble and recycled aggregates in self-compacting concrete for environmental sustainability. Journal of Cleaner Production 84: 691-700.

Wirquin E, Hadjieva-Zaharieva R and Buyle-Bodin F (2000) Use of water absorption by concrete as a criterion of the durability of concrete - application to recycled aggregate concrete. Materials and Structures 33(6): 403-408.

Zong L, Fei Z and Zhang S (2014) Permeability of recycled aggregate concrete containing fly ash and clay brick waste. Journal of Cleaner Production 70: 175-182.

\section{How can you contribute?}

To discuss this paper, please submit up to 500 words to the editor at journals@ice.org.uk. Your contribution will be forwarded to the author(s) for a reply and, if considered appropriate by the editorial board, it will be published as a discussion in a future issue of the journal. 